\title{
Technologies for Biogas Upgrading to Biomethane: A Review
}

\author{
Amir Izzuddin Adnan ${ }^{1}$, Mei Yin Ong ${ }^{1}\left(\mathbb{D}\right.$, Saifuddin Nomanbhay ${ }^{1, *}$, Kit Wayne Chew ${ }^{2}$ and \\ Pau Loke Show ${ }^{2}$ \\ 1 Institute of Sustainable Energy, Universiti Tenaga Nasional, Kajang 43000, Selangor, Malaysia; \\ izzuddin.amir95@gmail.com (A.I.A.); me089475@hotmail.com (M.Y.O.) \\ 2 Department of Chemical and Environmental Engineering, Faculty of Science and Engineering, University of \\ Nottingham Malaysia, Jalan Broga, Semenyih 43500, Selangor, Malaysia; \\ kitwayne.chew@gmail.com (K.W.C.); pauloke.show@nottingham.edu.my (P.L.S.) \\ * Correspondence: saifuddin@uniten.edu.my; Tel.: +6-03-8921-7285
}

Received: 17 September 2019; Accepted: 30 September 2019; Published: 2 October 2019

check for updates

\begin{abstract}
The environmental impacts and high long-term costs of poor waste disposal have pushed the industry to realize the potential of turning this problem into an economic and sustainable initiative. Anaerobic digestion and the production of biogas can provide an efficient means of meeting several objectives concerning energy, environmental, and waste management policy. Biogas contains methane $(60 \%)$ and carbon dioxide $(40 \%)$ as its principal constituent. Excluding methane, other gasses contained in biogas are considered as contaminants. Removal of these impurities, especially carbon dioxide, will increase the biogas quality for further use. Integrating biological processes into the bio-refinery that effectively consume carbon dioxide will become increasingly important. Such process integration could significantly improve the sustainability of the overall bio-refinery process. The biogas upgrading by utilization of carbon dioxide rather than removal of it is a suitable strategy in this direction. The present work is a critical review that summarizes state-of-the-art technologies for biogas upgrading with particular attention to the emerging biological methanation processes. It also discusses the future perspectives for overcoming the challenges associated with upgradation. While biogas offers a good substitution for fossil fuels, it still not a perfect solution for global greenhouse gas emissions and further research still needs to be conducted.
\end{abstract}

Keywords: anaerobic digestion; biogas upgrading; biomethane; bio-succinic acid; $\mathrm{CO}_{2}$ utilization; feasibility assessment

\section{Introduction}

In the last decades, fossil fuels have been utilized at a high rate as the main energy source for the industrial process as well as daily usage. The result is the increasing crisis of global energy and environmental problems. It has been predicted that the global consumption of energy will increase nearly threefold in the next thirty years [1]. Massive carbon dioxide $\left(\mathrm{CO}_{2}\right)$ emission during fossil fuel combustion has raised the concern on energy sustainability and environmental protection issues. The rate of $\mathrm{CO}_{2}$ that is presently being released at a global scale is more than $1000 \mathrm{~kg} / \mathrm{s}$, although it is the imbalance between emissions and sinks that is responsible for the increasing $\mathrm{CO}_{2}$ concentration in the atmosphere [2]. The reductions of $\mathrm{CO}_{2}$ emission into the atmosphere can only be achieved by either reducing the $\mathrm{CO}_{2}$ emissions from the sources or increasing the usage of $\mathrm{CO}_{2}$. A wide-ranging research plan is needed to develop a variety of carbon utilization technologies suitable for utilizing the abundance of carbon waste in the atmosphere, integrating enabling technologies and resources, and producing a wide range of carbon-based products. Therefore, extensive research needs to be 
conducted to address the knowledge gaps throughout the carbon utilization landscape in order to reduce greenhouse gas emissions (GHG) while generating economic value. The conversion of $\mathrm{CO}_{2}$ into added-value chemicals and fuels is considered as one of the great challenges of the 21st century.

To achieve sustainable development, energy resources with low environmental impact should be utilized. Besides petroleum, biomass is the largest source of carbon-rich material available on Earth [3]. Biorefineries represent tremendous potential for the efficient utilization of renewable resources. A biorefinery can be described as a facility that integrates biomass conversion processes and technologies in a sustainable and efficient way to produce a variety of marketable products (food, feed, chemicals, and materials) and energy (biofuels, power, and/or heat) from biomass. Biogas is a well-established renewable energy source for combined heat and power (CHP) generation. Biogas production is a treatment technology that generates renewable energy and recycles organic waste into a digested biomass, which can be used as fertilizer and soil amendment. Biogas is considered a renewable energy source due to the fact that the organic waste has consumed carbon dioxide in the photosynthesis process, and as such can be described as carbon-neutral [4]. The amount of wastes and residues generated has led to the demand for technologies and processes that can help to reduce these residues, which can help achieve the ambitious objective of "zero-waste" targets (or, at least, waste minimization) while obtaining valuable commodities, including renewable-based methane-rich product gas streams. In these regards, waste management technologies based on the anaerobic digestion of different residual streams, such as municipal solid wastes in landfills, agriculture crops, and urban wastewaters that allow the production of biogas, have played a significant role in the last decades. To date, efforts have been made to improve the methane $\left(\mathrm{CH}_{4}\right)$ yield during anaerobic digestion. Feedstock selection, process design and operation, digestion enhancement, and co-digestion with multiple substrates have been extensively studied, and several reviews are available [5-9].

Commercial biogas production has increased since it can be used as fuel or energy production while contributes to a lower GHG concentration when it is collected in a closed process and not emitted to the atmosphere. Depending on the nature of the substrate and $\mathrm{pH}$ of the reactor, biogas produced consists of $\mathrm{CH}_{4}$ in a range of $50-70 \%$ and $\mathrm{CO}_{2}$ at a concentration of $30-50 \%$, with the addition of minor components such as hydrogen sulfide $\left(\mathrm{H}_{2} \mathrm{~S}\right)$, nitrogen $\left(\mathrm{N}_{2}\right)$, oxygen $\left(\mathrm{O}_{2}\right)$, siloxanes, volatile organic compounds (VOCs), carbon monoxide $(\mathrm{CO})$, and ammonia $\left(\mathrm{NH}_{3}\right)$. It is estimated that biogas usage in the world will be doubled in the coming years, increasing from $14.5 \mathrm{GW}$ in 2012 to $29.5 \mathrm{GW}$ in $2022[10,11]$. Apart from $\mathrm{CH}_{4}$, the remaining components in biogas are undesirable and considered as impurities. Basically, there are two steps involved in biogas treatment, cleaning (removal of minor unwanted components of biogas), and upgrading (removal of $\mathrm{CO}_{2}$ content) $[10,11]$. After the processes, the final product is called biomethane which composed of $\mathrm{CH}_{4}(95-99 \%)$ and $\mathrm{CO}_{2}$ (1-5\%), with no trace of $\mathrm{H}_{2} \mathrm{~S}$. Biogas cleaning is usually considered the first step for biogas applications and is an energy-demanding process. The second treatment is called "biogas upgrading" and aims to increase the low calorific value of the biogas, and thus, to convert it to a higher fuel standard [12]. Nowadays, there are different treatments targeted at removing the undesired compounds from the biogas, thus expanding its range of applications. High $\mathrm{CH}_{4}$ purity biogas has the same properties as natural gas, especially in terms of heating value, therefore, this clean biogas is qualified to be injected into a natural gas grid [13]. An early notable review report on biogas upgrading was published in 2009, providing a complete view on the situation of biogas upgrading at that time, however, the topic on $\mathrm{CO}_{2}$ removal was only briefly discussed [14]. More review reports on biogas purification and upgrading had appeared recently. The first of them was by Ryckebosch and others (2011) [15] discussing the state of affairs of different techniques for biogas transformation and their functions, efficiency, and barriers. Next, Bauer et al. (2013) [16] reviewed and compared the commercial technologies on biogas upgrading. In later years, Sun et al. (2015) [12] had come out with a more detailed review on biogas upgrading technology, focusing on biogas purity and impurities, $\mathrm{CH}_{4}$ recovery and loss, upgrading efficiency, investment, and operating cost. These were among the many reviews that were conducted on the topic of biogas upgrading involving $\mathrm{CO}_{2}$ removal. Therefore, in this review, an attempt is made to 
present new technologies for biogas upgrading via the utilization and conversion of $\mathrm{CO}_{2}$ rather than the removal of $\mathrm{CO}_{2}$. The already matured technologies will only be briefly summarized.

\section{Biogas Upgrading via Carbon Dioxide Removal Technologies}

As a means to upgrade biogas to a higher fuel standard, that is, to remove unwanted components such as $\mathrm{CO}_{2}$ and $\mathrm{H}_{2} \mathrm{~S}$ thus increasing its specific caloric value, several different approaches have been proposed $[17,18]$. The mature technologies that are today currently applied for biogas upgrading are illustrated in Figure 1. The focus of this section is to summarize the important details regarding current $\mathrm{CO}_{2}$ removal technologies rather than going into details on it.

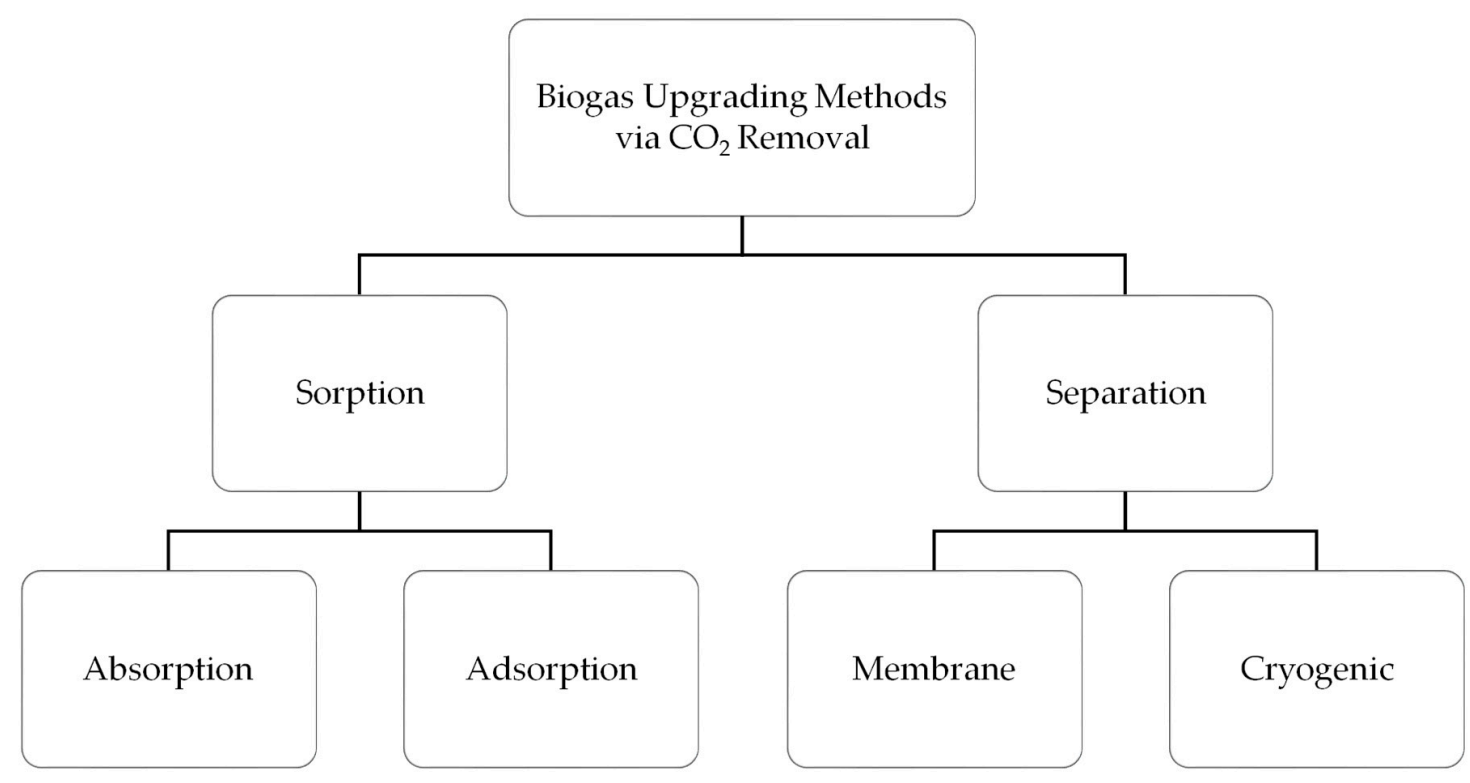

Figure 1. Technologies for biogas upgrading via $\mathrm{CO}_{2}$ removal route.

The gas sorption is divided into two categories: physical and chemical scrubbing. Physical scrubbing and chemical scrubbing processes were summarized in Figures 2 and 3 respectively. Next, the adsorption method was usually done in a process called pressure swing adsorption and can be seen as a summarized point in Figure 4. Then, the term separation is applied in membrane technology and cryogenic separation and depicted as in Figures 5 and 6, respectively. 


\section{Physical Scrubbing}

Working Principle

- $\mathrm{CO}_{2}$ is more soluble than $\mathrm{CH}_{4}$ according to

Henry's Law

- Raw biogas flow through a counter flow of a liquid in a column

- Liquid absorb $\mathrm{CO}_{2}$ leaving biogas with high content of $\mathrm{CH}_{4}$

Type of Liquid

- Water for water scrubbing

- Polyethylene glycol (PEG)/ Selexol ${ }^{\mathrm{TM}}$ and

Genesorb $^{\mathrm{TM}}$ for organic scrubbing

Current Status

- The most operated biogas upgrading plant among the IEA Bioenergy Task 37 member countries

- As of 2015, 152 units were operated

Feature Water

Power demand ( $€ / \mathrm{m}^{3}$ biogas) $\quad 0.25 \quad 0.32$

Pre-treatment None

Operation pressure (MPa) $\quad 0.4-1$

Outlet Pressure (MPa) $\quad 0.7-1$

Temperature $\left({ }^{\circ} \mathrm{C}\right)$

$\mathrm{CH}_{4}$ losses (\%)

$\mathrm{CH}_{4}$ purity (\%)

$<2$

96-98

Post-treatment
None

$0.4-0.8$

$0.13-0.75$

$55-80$

$2-4$

96-98

None

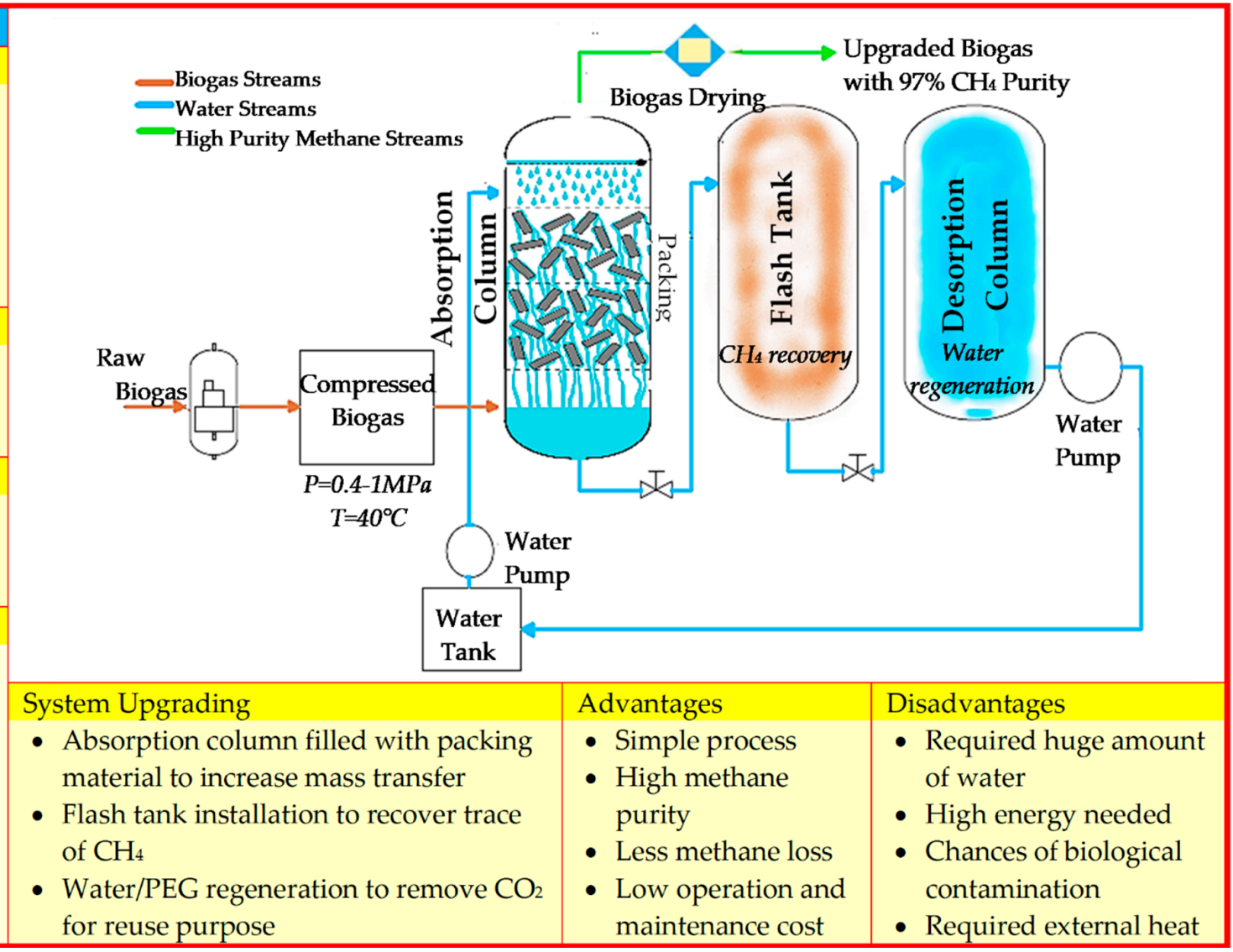

Figure 2. Summary of fundamental knowledge on physical scrubbing technology [15,19-28]. 


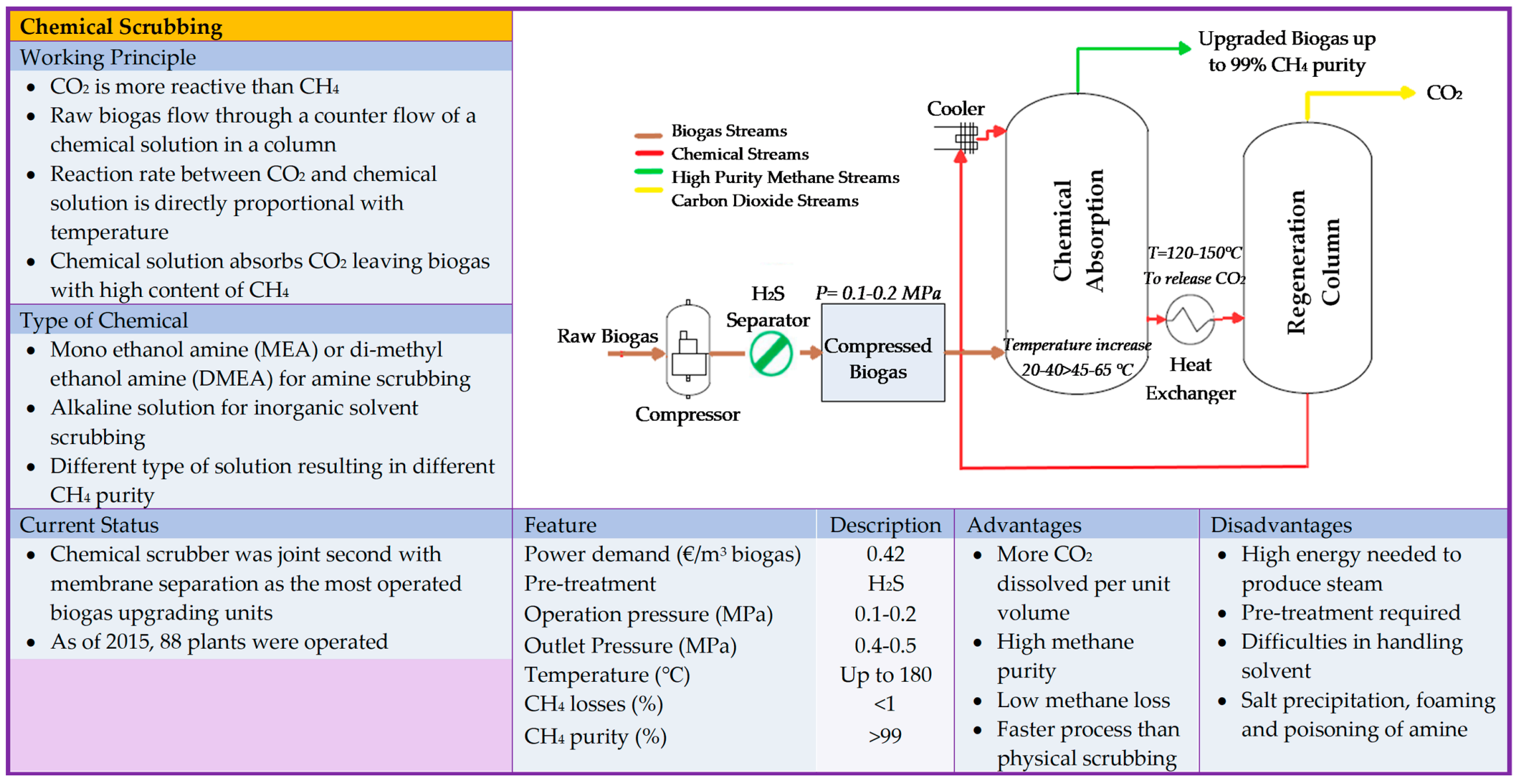

Figure 3. Summary of basic information on chemical scrubbing technology $[15,19,20,25,27-32]$. 


\section{Pressure Swing Adsorption}

Working Principle

- $\mathrm{CO}_{2}$ adsorb on surface of an adsorbent

by the van der Waals forces

- Pressure increase result in gas adsorbed and vice versa

- Four steps: adsorption,

depressurization, desorption and pressurization

Adsorption Techniques

- Pressure swing adsorption (PSA)

- Temperature swing adsorption (TSA)

- Electrical swing adsorption (ESA)

Adsorbent Material

- PSA: Carbon, zeolites

- TSA: Carbon cryogel microspheres (CCM) and carbon xerogel microspheres (CXM)

- ESA: Activated carbon

\section{System Upgrading}

- Multiple adsorption tank installed to ensure a continous operation

\section{Current Status}

- Fourth most operated biogas upgrading techniques with 88 units operating (data from 2015)

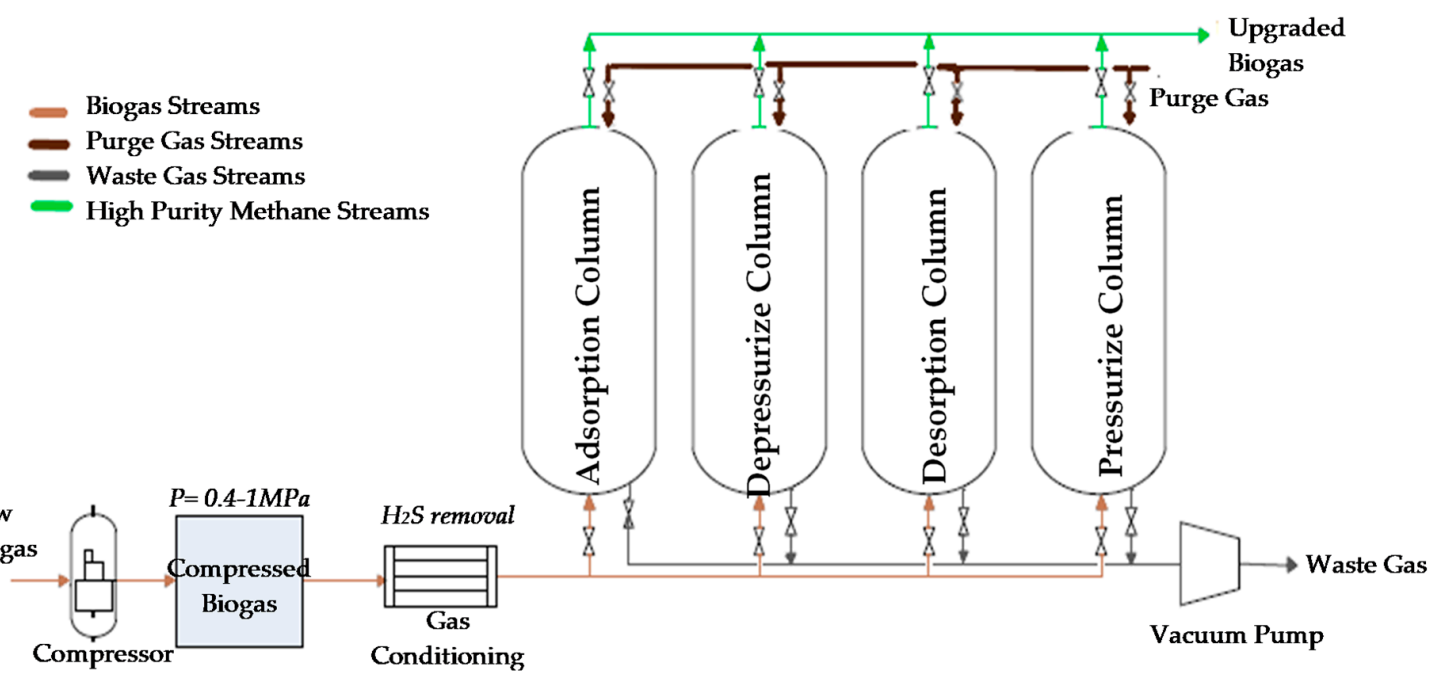

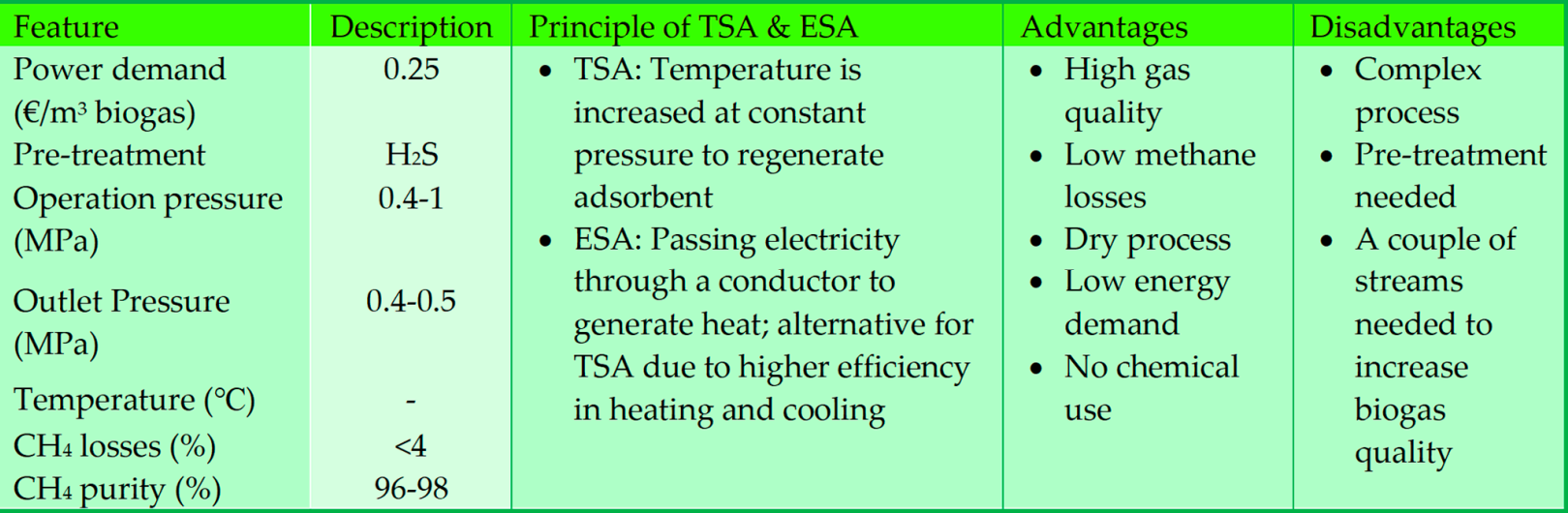

Figure 4. Depicts information on pressure swing adsorption technology [19,20,25,28,33-37]. 


Membrane Separation
$\begin{aligned} & \text { Working Principle } \\ & \text { - Separation of biogas components using membrane as } \\ & \text { permeable material }\end{aligned}$
- The selection of permeability properties of
membranes is crucial
- Ascending order of permeation rate: $\mathrm{CH}_{4}, \mathrm{~N}_{2}, \mathrm{H}_{2} \mathrm{~S}$,
$\mathrm{CO}_{2}$ and $\mathrm{H}_{2} \mathrm{O}$ )

Figure 5. Summary of base knowledge of membrane separation technology [20,21,25,27-29,38,39]. 


\section{Cryogenic Separation}

Working Principle

- Different gases condense at different temperature-pressure domains

- Boiling point of $\mathrm{CO}_{2}$ was higher than the $\mathrm{CH}_{4}$ thus allowing the separation

- Biomethane produced by gradual decrease of temperature and compressing the biogas

- Equipment: Compressor, turbine, heat exchanger, and cooler

Boiling Point

Pressure

Atmospheric

$1 \mathrm{MPa}$

\begin{tabular}{c|c|}
$\mathrm{CO}_{2}\left({ }^{\circ} \mathrm{C}\right)$ & $\mathrm{CH}_{4}\left({ }^{\circ} \mathrm{C}\right)$ \\
-78.2 & -161.5
\end{tabular}

Critical pressure:

$\mathrm{CO}_{2}=7.38 \mathrm{MPa}$

$-40$

$-123$

$\mathrm{CH}_{4}=4.60 \mathrm{MPa}$

31.21 $\mathrm{n} / \mathrm{a}$

Post-treatment

- Final product is in accordance with the quality standards for Liquefied Natural Gas (LNG)

- Further cooling for purification will produced Liquid Biomethane (LBM)

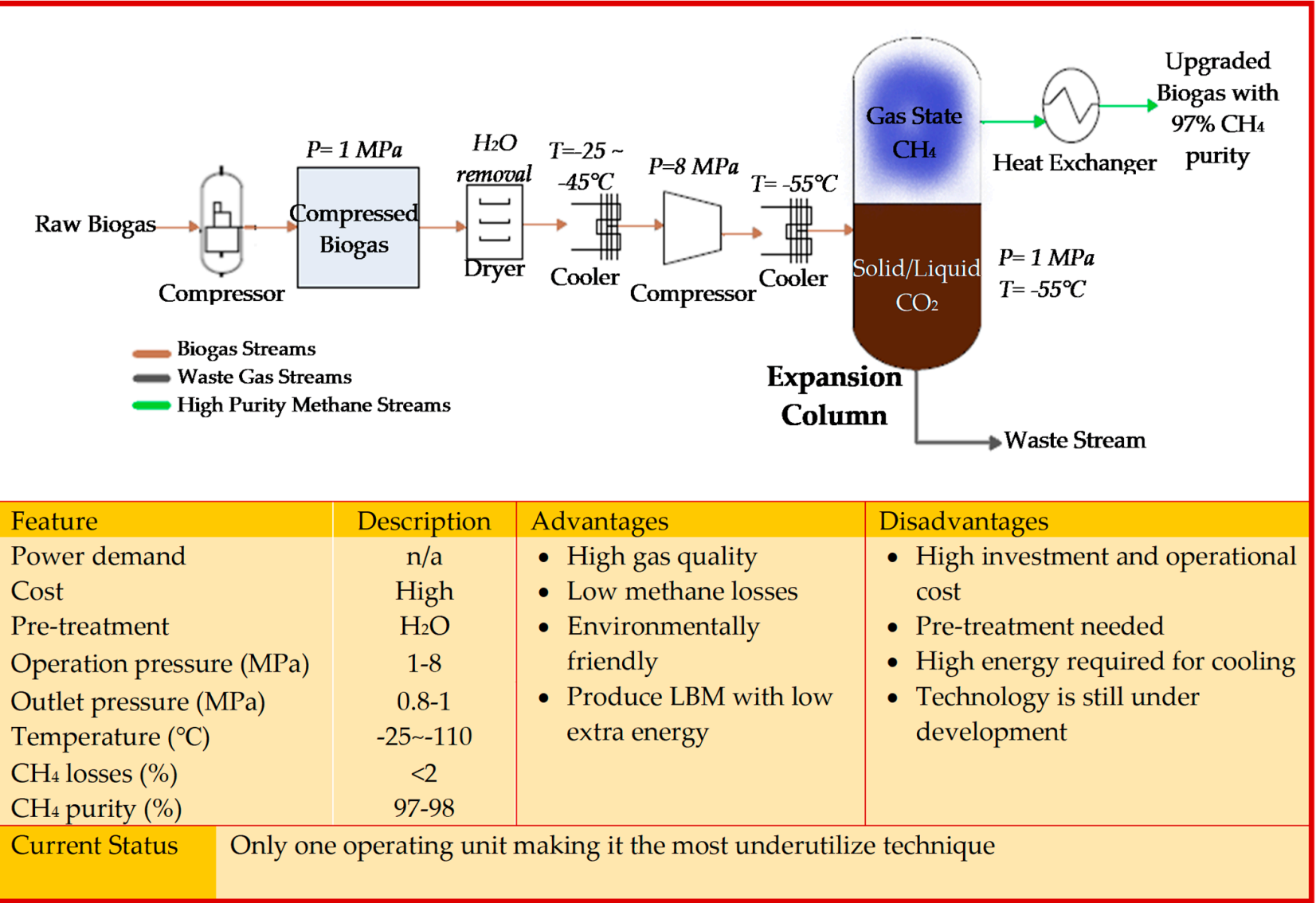

Figure 6. Depicts fundamental knowledge on cryogenic separation $[15,19,20,25,28,29,40-43]$. 
The benefits of biogas to the environment are often discussed as a sustainable source of fuels [44]. However, some biogas components released from biogas upgrading are associated with GHG, especially $\mathrm{CO}_{2}$. The direct impacts of excessive $\mathrm{CO}_{2}$ emission are global warming, ocean acidification, and carbon fertilization. The released $\mathrm{CO}_{2}$ needs to be disposed of. It includes the processes of $\mathrm{CO}_{2}$ liquifying and injection into underground aquifers. The drawback of this process is the possibility of $\mathrm{CO}_{2}$ leaking and returning to the surface. Furthermore, the cost of $\mathrm{CO}_{2}$ disposal is very high and uncertain (among the factors that contribute to cost are the size of the plant and the distance). Thus, a possible solution for this problem is through $\mathrm{CO}_{2}$ utilization technology. This technology holds big potential for a new way of upgrading biogas, since the benefits of utilizing $\mathrm{CO}_{2}$ could potentially overcome the cost of $\mathrm{CO}_{2}$ disposal and reduce the cost of biogas upgrading. The next section of this review will focus on the discussion of various techniques for the utilization of $\mathrm{CO}_{2}$ as reported in the literature.

\section{Biogas Upgrading via Carbon Dioxide Utilization Technologies}

In the previous section, biogas was upgraded to enrich the methane content and treated directly as fuel without essential chemical changes. The technologies are always changing, and researchers have developed methods to further explore the value of raw biogas. In recent years, biogas has been used as feedstock in producing chemical material by utilizing the $\mathrm{CO}_{2}$ content in the biogas [45]. In addition, this low-grade biogas will benefit society by the production of high-quality products instead of inefficient heat supply that results in higher pollution. This section will discuss the state-of-art of emerging technologies for biogas upgrading through $\mathrm{CO}_{2}$ utilization.

\subsection{Chemical Processes}

It is well known that using $\mathrm{CO}_{2}$ as a feedstock for the synthesis of commodity chemicals and fuels has the potential to be beneficial for the economy and environment [46]. $\mathrm{CO}_{2}$ with the molecular weight of 44.01 and critical density of $468 \mathrm{~kg} / \mathrm{m}^{3}$ can be in a liquid state at a pressure below $415.8 \mathrm{kPa}$ and in the form of solid under $-78^{\circ} \mathrm{C}$. It is a massively produced waste and the main contributor to global warming. Despite the potential, the challenges that arise from the utilization of $\mathrm{CO}_{2}$ are the need for large inputs of energy and the strong bonds that are not particularly reactive due to its kinetic and thermodynamic stability. For instance, it is not affected by heat under normal conditions until the temperature reaches about $2000{ }^{\circ} \mathrm{C}$ [47]. Consequently, the process of converting $\mathrm{CO}_{2}$ requires stoichiometric amounts of energy-intensive reagents that lead to the generation of other waste and increasing GHG footprints. Thus, the main challenge is to develop a new technology that can reduce the use of non-renewable energy and reduce GHG emissions.

Methanation reaction, also called a Sabatier reaction is a reaction between $\mathrm{CO}_{2}$ and $\mathrm{H}_{2}$ to produce $\mathrm{CH}_{4}$ and water $\left(\mathrm{H}_{2} \mathrm{O}\right)$. Although the reaction is between $\mathrm{CO}_{2}$ and $\mathrm{H}_{2}$, there is the potential of using biogas directly as feedstock for $\mathrm{CO}_{2}$ methanation as $\mathrm{CH}_{4}$ content in the biogas has only a little influence on the reaction at high pressure [48]. The research has found that the methanation of $\mathrm{CO}_{2}$ above $0.8 \mathrm{MPa}$ will be ideal to decrease the effect of $\mathrm{CH}_{4}$ on the conversion process [49]. $\mathrm{CH}_{4}$ is consumed by the consumer widely as a fuel in 2014 (3500 billion cubic meters) [50]. The main source of $\mathrm{CH}_{4}$ is natural gas, and occasionally as a result of synthetization. The process of hydrogenation of $\mathrm{CO}_{2}$ to $\mathrm{CH}_{4}$ using Ni catalyst is explained by Sabatier reaction in Equation (1) [51].

$$
\mathrm{CO}_{2}+4 \mathrm{H}_{2} \rightarrow \mathrm{CH}_{4}+2 \mathrm{H}_{2} \mathrm{O} \quad \Delta \mathrm{H}=-165 \mathrm{~kJ} / \mathrm{mol}
$$

The research in the improvement of catalysts is still developing. Challenges that need to be confronted include the catalysts that can operate at lower temperatures where the reaction more promising and preventing the deactivation of nickel-based catalysts due to sintering and oxidation. Sintering occurs due to the high temperature and water while oxidation is due to the presence of $\mathrm{H}_{2}[52,53]$. The improvement of catalysts and processes that have been recently discovered are simplified in Table 1. 
Table 1. Improvement of catalysts in methane production.

\begin{tabular}{ccc}
\hline Modification & Description/Results & Reference \\
\hline Ruthenium & More advanced than nickel but costly & {$[54]$} \\
Electrochemical & Using the standard three-electrode or H cells & F5-57] \\
N-doped carbon & Faradaic efficiencies $80 \%$ to $94 \%$ & \\
Copper-on-carbon & Electrodeposited on a carbon gas diffusion electrode & [56] \\
Copper & $38 \mathrm{~mA} / \mathrm{cm}^{2}$ densities of methane formation & \\
\hline
\end{tabular}

On the other hand, by changing the nature of catalysts to less reactive catalysts result in the production of methanol. In 2015, approximately 70 billion $\mathrm{kg}$ of methanol $\left(\mathrm{CH}_{3} \mathrm{OH}\right)$ was produced worldwide from the synthetization of syngas $\left(\mathrm{H}_{2}+\mathrm{CO}_{2}\right)$ obtained directly from fossil fuels [58-61]. The mechanism of methanol production, seen in Equation (2), involves a side reaction between $\mathrm{CO}_{2}$ and $\mathrm{H}_{2}$ to produce $\mathrm{CO}$ and $\mathrm{H}_{2} \mathrm{O}$ based on water gas-shift reaction as shown by Equation (3).

$$
\begin{array}{cc}
\mathrm{CO}_{2}+3 \mathrm{H}_{2} \leftrightarrow \mathrm{CH}_{3} \mathrm{OH}+\mathrm{H}_{2} \mathrm{O} & \Delta \mathrm{H}_{298 \mathrm{~K}}=-90.70 \mathrm{~kJ} / \mathrm{mol} \\
\mathrm{H}_{2}+\mathrm{CO}_{2} \leftrightarrow \mathrm{CO}+\mathrm{H}_{2} \mathrm{O} & \Delta \mathrm{H}_{298 \mathrm{~K}}=41.19 \mathrm{~kJ} \mathrm{~mol}
\end{array}
$$

The methanol formation here is an exothermic reaction and the molecular weight of molecules with carbon decrease. Thus, there will be an increase in pressure and a decrease in temperature for selectivity. But, as mentioned earlier, $\mathrm{CO}_{2}$ is not very reactive and needs a high reaction temperature $\left(>513 \mathrm{~K}\right.$ ) for $\mathrm{CO}_{2}$ conversion to occur. In recent years, a lot of research has been done on the catalysts used for direct hydrogenation of $\mathrm{CO}_{2}$ to methanol, and the results have shown that high pressure is needed to achieve high methanol selectivity $[58,62,63]$. The most suitable catalyst is not yet available in the current industry. Two challenges for catalyst development are the huge amount of water produced by both reactions that inhibit the product and the undesirable reverse water gas-shift reaction that consumes hydrogen, thus results in a decrease in the yield for methanol. Copper-zinc-aluminum oxide catalyst is often used in $\mathrm{CO}_{2}$ hydrogenation. The process is run at 5.0-10.0 MPa and 473-523 K. But, the catalyst is not effective again for hydrogenating pure $\mathrm{CO}_{2}$ [64]. Significant amounts of research into the direct hydrogenation of $\mathrm{CO}_{2}$ to methanol is continuing. Some of the researches are simplified in Table 2.

Table 2. Modification of direct hydrogenation of $\mathrm{CO}_{2}$ to methanol.

\begin{tabular}{ccc}
\hline Modification & Description/Result & Reference \\
\hline Transition metal carbides: & High $\begin{array}{c}\mathrm{CO}_{2} \text { conversion and good } \\
\text { methanol selectivity } \\
\text { Almost inactive }\end{array}$ & [65] \\
$\begin{array}{c}\text { 1. Molybdenum carbide }\left(\mathrm{Mo}_{2} \mathrm{C}\right) \text { and cementite }\left(\mathrm{Fe}_{3} \mathrm{C}\right) \\
\text { 2. Tantalum carbide }(\mathrm{TaC}) \text { and Silicon carbide }(\mathrm{SiC})\end{array}$ & Higher performance & {$[66]$} \\
\hline Two-stage bed system & Based on CO hydrogenation & {$[59]$} \\
\hline Heterogeneous copper-based catalysts & $\begin{array}{c}\text { Produce methanol with 70\% of } \\
\text { Faradaic efficiency with } \\
\text { Molybdenum-bismuth bimetallic chalcogenide } \\
\text { electrocatalyst }\end{array}$ & $\begin{array}{c}\text { requirement of acetonitrile/ionic } \\
\text { liquid electrolyte solution }\end{array}$ \\
\hline
\end{tabular}

Another product that can be obtained from the methanation of $\mathrm{CO}_{2}$ is carbon monoxide. $\mathrm{CO}$ is usually obtained through partial oxidation of hydrocarbons or coal at high temperatures around 800 ${ }^{\circ} \mathrm{C}$. CO is a valuable feedstock in the synthesis of different commodities such as methanol and other higher-order hydrocarbons. The method of obtaining $\mathrm{CO}$ from $\mathrm{CO}_{2}$ from the methanation process is the reverse water-gas shift reaction (shown in Equation (3)) as the major by-product [68]. The 
reaction is endothermic and requires s high temperature $\left(\sim 500^{\circ} \mathrm{C}\right)$. A wide range of heterogeneous catalysts often used are copper-, iron-, or ceria-based systems for the reverse water-gas shift reaction. The problems of these catalysts are poor thermal stability and undesired side product often formed. Due to this thermodynamic constraint, it is unlikely for the research on converting $\mathrm{CO}_{2}$ to $\mathrm{CO}$ using reverse water-gas shift reaction to advance beyond this stage. Furthermore, there are other potential routes to generate $\mathrm{CO}$ from $\mathrm{CO}_{2}$ at a significantly more advanced state. To directly reduce $\mathrm{CO}_{2}$ to $\mathrm{CO}$ and $\mathrm{O}_{2}$, the use of electrochemical splitting provides an alternative way. Unfortunately, the subject will not be discussed further in this paper, but information on the process can be obtained here $[69,70]$.

\subsection{Biological Processes}

Biological processes complement chemical options due to its uniqueness of carbon utilization resource requirements and product opportunities. It focuses on the aptitude of microorganisms to convert $\mathrm{CO}_{2}$ into useful products. Biological fixation of $\mathrm{CO}_{2}$ is a sustainable solution to reduce $\mathrm{CO}_{2}$ content in biogas due to its nature which is environmentally-friendly and eliminates the step of captured $\mathrm{CO}_{2}$ disposal [71]. One of the biological methods to utilize $\mathrm{CO}_{2}$ in biogas relies on the utilization of $\mathrm{H}_{2}$ for the conversion of $\mathrm{CO}_{2}$ to $\mathrm{CH}_{4}$ based on the action of hydrogenotrophic methanogens. The reaction is shown in Equation (4).

$$
4 \mathrm{H}_{2}+\mathrm{CO}_{2} \rightarrow \mathrm{CH}_{4}+2 \mathrm{H}_{2} \mathrm{O} \quad \Delta \mathrm{G}^{\circ}=-130.7 \mathrm{~kJ} / \mathrm{mol}
$$

The source of $\mathrm{H}_{2}$ is the hydrolysis of water. To ensure the method is sustainable, electricity needed in the hydrolysis process came from renewable sources, such as solar and wind. One of the disadvantages of $\mathrm{H}_{2}$ was its low volumetric energy density, resulting in storage difficulties [72]. This $\mathrm{H}_{2}$ assisted biogas upgrading can occur in a so-called in-situ and ex-situ biological biogas upgrading. Ex-situ upgrading had been discussed in previous sections and includes absorption, adsorption, membrane separation, and cryogenic methods. It requires the $\mathrm{CO}_{2}$ to be removed first, thus defeating the purpose of utilizing the $\mathrm{CO}_{2}$ in biogas, which is the focus of this topic. Ex-situ upgrading will not be discussed further but the review can be found here [73]. Meanwhile, the process of in-situ upgrading does not require the $\mathrm{CO}_{2}$ to be removed first, rather it will be converted into $\mathrm{CH}_{4}$ leading to a significant increment in biogas purity [13].

In-situ biological biogas upgrading uses the injection of $\mathrm{H}_{2}$ inside a biogas reactor during anaerobic digestion to react with $\mathrm{CO}_{2}$, resulting in $\mathrm{CH}_{4}$ production by the action of autochthonous methanogenic archaea [13]. This can be operated through two different pathways: hydrogenotrophic methanogenesis and Wood-Ljungdahl [74]. Hydrogenotrophic methanogenesis performs direct conversion of $\mathrm{CO}_{2}$ to $\mathrm{CH}_{4}$ with the addition of $\mathrm{H}_{2}$ as a source of electrons, according to Equation (4). Meanwhile the Wood-Ljungdahl pathway indirectly converts $\mathrm{CO}_{2}$ to $\mathrm{CH}_{4}$ via two reactions according to Equations (5) and (6).

$$
\begin{gathered}
4 \mathrm{H}_{2}+2 \mathrm{CO}_{2} \rightarrow \mathrm{CH}_{3} \mathrm{COOH}+2 \mathrm{H}_{2} \mathrm{O} \quad \Delta \mathrm{G}^{\circ}=-104.5 \mathrm{~kJ} / \mathrm{mol} \\
\mathrm{CH}_{3} \mathrm{COOH} \rightarrow \mathrm{CH}_{4}+\mathrm{CO}_{2} \quad \Delta \mathrm{G}^{\circ}=-31.0 \mathrm{~kJ} / \mathrm{mol}
\end{gathered}
$$

The $\mathrm{CO}_{2}$ is converted to acetate acid with the help of homoacetogenic bacteria. Then the acetate acid is converted into $\mathrm{CH}_{4}$ with the present of acetoclastic methanogenic archaea. $\mathrm{H}_{2}$ plays a crucial role in the whole process of anaerobic digestion. Exogenous addition of $\mathrm{H}_{2}$ results in the increase of both hydrogenotrophic methanogens and homoacetogenic species, producing acetate from $\mathrm{H}_{2}$ and $\mathrm{CO}_{2}$ [75]. The downside of adding $\mathrm{H}_{2}$ to the process is the inhibition of syntrophic acetogens which are involved in propionate and butyrate degradation and syntrophic acetate oxidizers (SAO) [76]. It is important to control the concentration of $\mathrm{H}_{2}$ to ensure the equilibrium of biochemical reactions. The process is illustrated in Figure 7. 


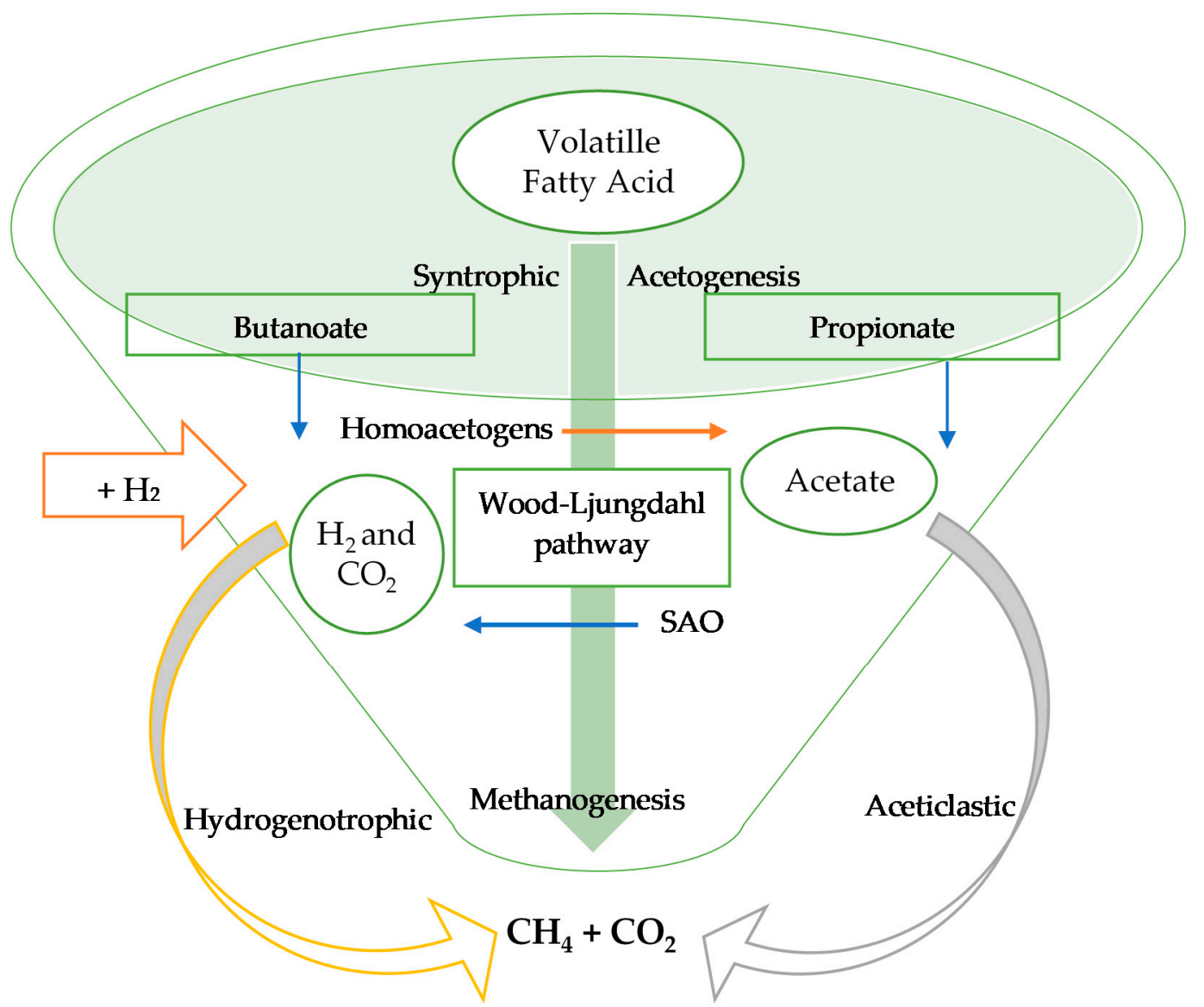

Figure 7. Metabolic pathways for hydrogen assisted methanogenesis [25].

One type of biogas reactor often used in this process is called "continuous stirred tank reactor" (CSTR). The process is heavily connected to the $\mathrm{pH}$ level in the reactor. The main challenge is to prevent a $\mathrm{pH}$ value above 8.5 because it will lead to methanogenesis inhibition $[77,78]$. Another challenge arises from the oxidation of the volatile fatty acid (VFA) and alcohols associated with the concentration of the injected hydrogen. To prevent the increasing of the $\mathrm{pH}$ level and VFA oxidation, co-digestion with acidic waste [79] and injection of high $\mathrm{H}_{2}$ concentrations in reactor [80] were proposed to solve the problems, respectively. Additionally, a ton of research had been done on how to increase the efficiency of the process. A select few of these are listed in Table 3.

Table 3. In-situ enriched $\mathrm{H}_{2}$ upgrading technologies.

\begin{tabular}{|c|c|c|c|c|c|c|c|c|c|}
\hline Reactor Type & Upgrading Technology & Substrate & $\begin{array}{c}\text { Temperature } \\
\left({ }^{\circ} \mathrm{C}\right)\end{array}$ & $\begin{array}{c}\text { HRT } \\
\text { (days) }\end{array}$ & $\begin{array}{c}\mathrm{H}_{2} \text { Flow } \\
\text { (L/L-days) }\end{array}$ & $\mathrm{pH}$ & $\begin{array}{l}\mathrm{CH}_{4} \\
(\%)\end{array}$ & $\begin{array}{l}\mathrm{CO}_{2} \\
(\%)\end{array}$ & Reference \\
\hline $\begin{array}{l}1.5 \text { (R1) and 2L } \\
\text { (R2) CSTR }\end{array}$ & $\begin{array}{l}\text { a) Mesophilic digester } \\
\text { with external } \mathrm{H}_{2} \text { addition } \\
\text { b) Thermophilic digester } \\
\text { with external } \mathrm{H}_{2} \text { addition }\end{array}$ & $\begin{array}{l}\text { Cattle } \\
\text { ma-nure }\end{array}$ & $35-55$ & $\begin{array}{l}\mathrm{R} 1=25 \\
\mathrm{R} 2=20\end{array}$ & $\begin{array}{l}\mathrm{R} 1=0.192 \\
\mathrm{R} 2=0.510\end{array}$ & $\begin{array}{l}\mathrm{R} 1=7.78 \\
\mathrm{R} 2=7.95\end{array}$ & $\begin{array}{l}89 \\
85\end{array}$ & $\begin{array}{l}7 \\
9\end{array}$ & [78] \\
\hline $\begin{array}{c}120 \mathrm{~mL} \\
\text { Batch bottle }\end{array}$ & Exogenous $\mathrm{H}_{2}$ addition & $\begin{array}{c}\text { Maize } \\
\text { Leaf }\end{array}$ & 52 & 24 & $0.04-0.10$ & $7-8$ & $88-89$ & $10-12$ & [81] \\
\hline $\begin{array}{l}\text { Two } 600 \mathrm{~mL} \\
\text { CSTR }\end{array}$ & $\begin{array}{l}\text { Co-digested substrates } \\
\text { with exogenous } \mathrm{H}_{2} \\
\text { addition }\end{array}$ & $\begin{array}{c}\text { Cattle } \\
\text { ma-nure } \\
\text { and whey }\end{array}$ & 55 & 15 & $1.5-1.7$ & $7.7-7.9$ & $53-75$ & $6.6-13$ & [79] \\
\hline Two 3.5 L CSTR & $\mathrm{H}_{2}$ addition & $\begin{array}{l}\text { Cattle } \\
\text { ma-nure }\end{array}$ & 55 & 14 & $28.6 \mathrm{~mL} / \mathrm{L} / \mathrm{h}$ & 8.3 & 68 & 12 & [82] \\
\hline
\end{tabular}




\subsection{Assessment on Feasibility of Biogas Upgrading}

In methanation and biological reaction, costs that need to be considered are investment and operational costs, on top of costs associated with $\mathrm{H}_{2}$ electrolysis and methanation. Assumptions made were that a large-scale plant for conversion was constructed and that the declining future cost for $\mathrm{H}_{2}$ electrolysis was achieved due to the higher market penetration rate.

\subsubsection{Cost Estimation}

$\mathrm{H}_{2}$ electrolysis involves the production of $\mathrm{H}_{2}$ and $\mathrm{O}_{2}$ from electricity (renewable) and water. There are two techniques that can carry out hydrolysis, the low-temperature process, and the hightemperature process. However, the lack of flexibility of high-temperature electrolysis had impaired the use of it [83]. Thus, a further assumption was made based on the low-temperature process. Based on these assumptions, investment costs obtained were in the range of $656-768 € / \mathrm{kW}$; the operating costs were about four percent of it; efficiency was $67 \%$; and electricity consumption was $4.1 \mathrm{kWh} / \mathrm{m}^{3}[84,85]$. The cost of water supply is negligible because it was considered less relevant and can be obtained from the methanation reaction.

For the methanation reaction, besides investment and operating cost, there were costs for capturing $\mathrm{CO}_{2}$ from biogas and $\mathrm{H}_{2}$ storage. Assuming the implementation of the system was at well-established biogas upgrading units, the cost can be neglected. During methanation, heat was released and will be used to capture the $\mathrm{CO}_{2}$ from the biogas, resulting in zero cost on heat generation. The water obtained can be used for $\mathrm{H}_{2}$ hydrolysis. The storage of $\mathrm{H}_{2}$ in steel tanks is a well-established technology and can be put at $27 € / \mathrm{kWh}$ as investment costs [86]. The investment cost for the methanation plant can be assumed in the range of $652-785 € / \mathrm{kW}$; and the operating costs were about four percent of it [85]. However, for biological process, the technique is still under development and the cost cannot be estimated.

In addition, estimation of producing methanol from biogas was done by Zhang et al. (2017) [87]. In the literature, different analyses are taken to calculate the cost. For a plant scale of $5 \times 10^{6} \mathrm{~kg} /$ day methanol, the total cost will be in range of USD 827 million to USD 1036 million. For comparison, capital cost for fossil fuel-based methanol was around USD 480 million [88]. From an economical point of view, it can be concluded that industrial exploitation of biogas has a long path ahead of them to be on the same level with current fossil fuel-based processes. For sure, by upgrading biogas by converting $\mathrm{CO}_{2}$ to methane and methanol is relevant but is now not a viable short-term benefit when compared to already established technologies.

\subsubsection{Advantages and Disadvantages}

The created mixture in the form of biomethane has a strong resemblance to natural gas. Thus, the distribution of biomethane can be done from existing gas pipelines. This displays a major advantage, as the infrastructure for transporting the biomethane already exists. In contrast to $\mathrm{H}_{2}$, new distribution network is needed if it became the main energy carrier. Second, production of biomethane can help balance the electric grid. For example, renewables energy such as solar and wind are intermittent and not flexible enough. By producing biomethane, it helps to make use of excess electricity produced whenever the demand is low. On the other hand, biomethane can be used as fuel in a power plant when the demand is high and exceeding the limit of produced electricity. Finally, unlike electricity, biomethane is carbon neutral and can be stored efficiently for future use.

One of the drawbacks of the technique is low efficiency. When converting biogas into biomethane using $\mathrm{H}_{2}$, the efficiency is only $60 \%$. In addition, if the biomethane produced was to be used to produce electricity, the efficiency drops to $36 \%$. After analyzing the cost, a question is raised: is this technique economically viable? At the moment, the technique is not viable. However, it is likely to be possible in the future when a system with a large share of intermittent renewables are available. 


\section{Novel Technologies in Carbon Dioxide Conversion}

In recent years, the development of new technologies has resulted in the production of a useful commodity by the discovery of new converting processes of $\mathrm{CO}_{2}$ from waste and atmosphere. These efforts led to the limiting of GHG emissions to the atmosphere of climate-altering pollutants. While $\mathrm{CO}_{2}$ has been safely used for enhanced oil and carbon feedstock, there is an increased focus on identifying options for re-use of $\mathrm{CO}_{2}$ for other purposes. There were three stages of development in $\mathrm{CO}_{2}$ conversion technologies, which can be classified as past, present, and future [65]. In the past, $\mathrm{CO}_{2}$ conversion technologies focused on producing urea, methanol, cyclic carbonate, and salicylic acid. Then its focus shifted to the making of $\mathrm{CO}_{2}$ based polymers, fuels, and reactions such as methanation and dry reforming. Meanwhile, $\mathrm{CO}_{2}$ conversion technologies in the future are predicted to be focusing on production of carboxylic and succinic acid (SA). Thus, this section will be focusing on the possibility of producing $\mathrm{SA}$ from $\mathrm{CO}_{2}$ components in biogas.

SA $\left(\mathrm{C}_{4} \mathrm{H}_{6} \mathrm{O}_{4}\right)$, also known as butanedioic acid is a four-carbon diacid used as a platform for synthesis of various commodities as shown in Figure 8. It is mostly produced from LPG or petroleum oil through specific chemical process. Although, recent analysis revealed that production of bio-SA from bacterial fermentation, which is a renewable source, can be more cost-effective than the traditional processes [89]. In recent years, the advancement of bio-based production of SA was very significant, and as a consequence, a variety of microorganisms has been engineered for the synthesis of SA from sugars, glycerol, or acetate [90]. Furthermore, the $\mathrm{CO}_{2}$ is fixed into the bacteria reducing the greenhouse gas emission that lead to pollution. In fact, carbon footprint of bio-SA production is $0.85 \mathrm{~kg} \mathrm{CO}$ eq/ $/ \mathrm{kg}$ compared to $1.8 \mathrm{~kg} \mathrm{CO}$ eq $/ \mathrm{kg}$ of carbon footprint by petroleum-based SA [91]. One way to operate a $\mathrm{CO}_{2}$ fixation process is through reductive tricarboxylic acid (TCA) cycle. In this anaerobic SA production which fully operated under pure $\mathrm{CO}_{2}$ condition, $1 \mathrm{~mol} \mathrm{CO}_{2}$ can produce 1 mol of SA [92]. However, to establish a truly circular bio-economy and utilizing the abundant industrial by-product of $\mathrm{CO}_{2}$, valorization of $\mathrm{CO}_{2}$ as a substitute to the sugar-based substrates is today of particular relevance [93]. Moreover, if the off-gas from biogas industries could be effectively utilized as $\mathrm{a} \mathrm{CO}_{2}$ source for $\mathrm{SA}$ fermentation, it will simultaneously decrease the cost of the whole process while meeting the commercial-scale requirements for natural gas grid [94].

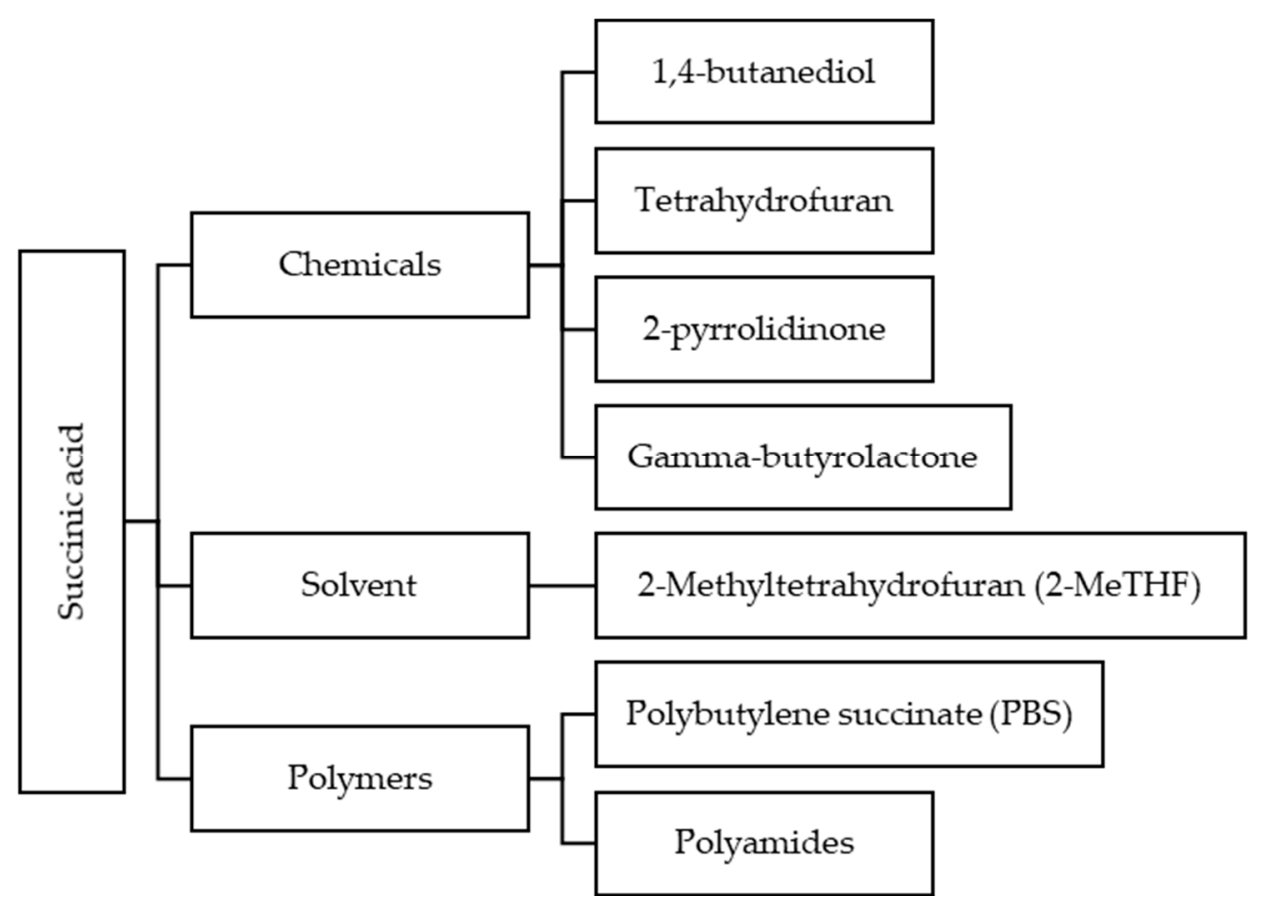

Figure 8. Potential products by using succinic acid (SA) as feedstock [95]. 


\subsection{Simultaneous Biogas Upgrading and Bio-Succinic Acid Production}

As mentioned earlier, biogas consists of $60 \% \mathrm{CH}_{4}$ and $40 \% \mathrm{CO}_{2}$. The presence of $\mathrm{CO}_{2}$ limits the use of biogas. In 2014, Gunnarsson et al. (2014) [96] had come out with a novel approach for converting the $\mathrm{CO}_{2}$ component in biogas into SA through a biological process. The study demonstrates a new biogas upgrading technology, which makes use of bacterial fermentation to simultaneously produce high-purity $\mathrm{CH}_{4}$ and bio-SA. The microorganism used was a strain of Actinobacillus succinogenes $130 \mathrm{Z}$ (DSM 22257). Application properties are as follows: Substrate: Glucose 30-32 g/L; reactors: 3-L; T: $37^{\circ} \mathrm{C}$; pH: 6.75; $\omega: 200 \mathrm{rpm}$; t: 24 h; P: 101.325 and $140 \mathrm{kPa}$; gas-liquid ratio: 8.3:1 and 5:1. The results of the study are tabulated in Table 4 . Stages of the processes are simplified in Equation (7).

$$
\begin{gathered}
\text { Substrate }\left(\text { Anaerobic digestion) } \rightarrow \text { Biogas }\left(60 \% \mathrm{CH}_{4} 40 \% \mathrm{CO}_{2}\right)\right. \text { (Fermentation) } \\
\qquad \text { Natural Gas }\left(95 \% \mathrm{CH}_{4}\right)+\text { Succinate }
\end{gathered}
$$

Based on Table 4, slight over-pressure during fermentation was ideal for the solubility of $\mathrm{CO}_{2}$, thus increasing the $\mathrm{CH}_{4}$ content in biogas. Increasing the pressure while reducing the ratio also affects other parameters, as $\mathrm{CO}_{2}$ consumption rate increased by $16.4 \%$, SA concentration increased by $6.2 \%$, and SA yield increased by $13.8 \%$. The final $95 \% \mathrm{CH}_{4}$ purity produced was similar to that of commercial biogas upgrading technologies (95-98\%) [21]. This study sparks vast potentials for future investigation on the large-scale implementation for practical application in industries. Then in 2018, a group of inspired researchers from Germany, led by Patrick Ballmann, provided a plan to further study this new concept of simultaneous upgrading by replacing the glucose with lignocelluloses from straw [97]. A further modification was done on the straw to provide a suitable strain for SA production while reducing the by-products. To this state, only A. succinogenes has been used for SA production coupled with biogas upgrading [25]. That remained the case for a few years until Babaei et al. (2019) [98] conducted an experiment using Basfia succiniciproducens (DSM 22022) as a bacterial strain for the fermentation of SA.

Table 4. Performance of the system at different pressure and gas-liquid ratio.

\begin{tabular}{ccccc}
\hline & \multicolumn{4}{c}{ Pressure (kPa) } \\
Gas-liquid ratio & $\mathbf{1 0 1 . 3 2 5}$ & \multicolumn{2}{c}{$\mathbf{1 4 0}$} \\
\hline $\mathrm{CO}_{2}$ solubility $(\mathrm{mM})$ & 9.15 & $\mathbf{5 : 1}$ & $\mathbf{8 . 3 : 1}$ & $\mathbf{5 : 1}$ \\
\hline $\mathrm{CO}_{2}$ fixation rate $(\mathrm{L} \mathrm{CO} / \mathrm{L}-\mathrm{d})$ & 1.35 & 1.52 & 2.59 & 16.7 \\
$\mathrm{CH}_{4}$ purity $(\%)$ & 76.4 & 85.2 & 91.1 & 95.4 \\
SA yield $(\mathrm{g} / \mathrm{g})$ & 0.60 & 0.56 & 0.62 & 0.63 \\
SA productivity $(\mathrm{g} / \mathrm{L}-\mathrm{h})$ & 0.53 & 0.53 & 0.60 & 0.56 \\
SA concentration $(\mathrm{g} / \mathrm{L})$ & 12.85 & 12.74 & 14.39 & 13.53 \\
By-products concentration $(\mathrm{g} / \mathrm{L})$ & 9.5 & 11.63 & 8.65 & 9.96 \\
\hline
\end{tabular}

The experiment conducted by Babaei et al. (2019) [98] was to determine the possibilities of expanding the simultaneous SA production with a biogas upgrading process by using organic fraction of household kitchen waste (OFHKW) as substrate, replacing the common use of glucose while comparing the performance of A. succinogenes and B. succiniciproducens in producing SA. OFHKW was broken down by enzymatic hydrolysis to produce monomeric fermentable sugars prior to the fermentation process. The experiment was divided by two major parts: The first was to determine the condition for B. succiniciproducens to produce SA, the second was to prove the ability of B. succiniciproducens to conduct a simultaneous biogas upgrading with SA production. Application properties, results, and discussion of the study are simplified in Table 5. 
Table 5. Summary of the fermentation process using either B. succiniciproducens or $A$. succinogenes as bacterial strain.

\begin{tabular}{|c|c|c|c|c|}
\hline \multicolumn{2}{|c|}{ Task } & Application Properties & Results & Discussion \\
\hline $\begin{array}{l}\text { Simultaneous } \\
\text { Upgrading }\end{array}$ & B. succiniciproducens & $\begin{array}{l}\text { Carbon source: } \mathrm{MgCO}_{3} \\
\text { 5-100 g/L; Substrate: } \\
\text { OFHKW 17, 25, } 35 \& 60 \mathrm{~g} / \mathrm{L} ; \\
\text { Serum bottles: } 250-\mathrm{mL} ; \mathrm{T}: 37 \\
{ }^{\circ} \mathrm{C} ; \mathrm{pH}: 6.7 \pm 0.1 ; \omega: 150 \mathrm{rpm} \\
\text { Carbon source: Biogas; } \\
\text { Substrate: OFHKW } 17 \mathrm{~g} / \mathrm{L} ; \\
\text { Reactors: } 3-\mathrm{L} ; \mathrm{T}: 37^{\circ} \mathrm{C} ; \mathrm{pH}: \\
\text { 6.7; } \omega: 200 \mathrm{rpm} \text { t: } 8 \mathrm{~h} ; \mathrm{P}: 130 \\
\& 140 \mathrm{kPa} \\
\text { Carbon source: Biogas; } \\
\text { Substrate: Glucose } 32 \mathrm{~g} / \mathrm{L} ; \\
\text { Reactors: } 3-\mathrm{L} ; \mathrm{T}: 37^{\circ} \mathrm{C} ; \mathrm{pH}: \\
\text { 6.75; } \omega: 200 \mathrm{rpm} \text { t: } 24 \mathrm{~h} ; \mathrm{P}: \\
\text { 101.325 \& } 140 \mathrm{kPa}\end{array}$ & $\begin{array}{c}\text { B. succiniciproducens } \\
\text { SA concentration: Maximum } \\
\text { titer of } 17.9 \pm 0.43 \mathrm{~g} / \mathrm{L} ; \\
\text { Overall reaction: Substrate }+ \\
2 \mathrm{CO}_{2} \rightarrow 2 \text { lactate }+2 \text { acetate } \\
+2 \text { formate } \\
\text { A. succinogenes } \\
\text { SA concentration: Maximum } \\
\text { titer of } 21.1 \pm 3.5 \mathrm{~g} / \mathrm{L} \\
\mathrm{SA} \text { concentration: } 3.8 \pm 0.8 \\
\mathrm{~g} / \mathrm{L}\left(0.25 \mathrm{~g}_{\mathrm{SA}} / \mathrm{g}_{\mathrm{glucose}}\right) ; \mathrm{CO}_{2} \\
\text { content: } 8.0 \%(\mathrm{v} / \mathrm{v}) \\
\text { reduction; } \mathrm{CH}_{4} \text { content: } \\
4.7 \%(\mathrm{v} / \mathrm{v}) \text { increase } \\
\\
\mathrm{SA} \text { concentration: } 14.39 \mathrm{~g} / \mathrm{L} ; \\
\mathrm{CH}_{4} \text { content: } 31 \%(\mathrm{v} / \mathrm{v}) \\
\text { increase }\end{array}$ & $\begin{array}{l}\text { In term of duration and sugar } \\
\text { consumption rate, } B \text {. } \\
\text { succiniciproducens }(8 \mathrm{~h}) \text { is still superior } \\
\text { than } A \text {. succinogenes }(24 \mathrm{~h}) \text {; The best } \\
\text { way to conduct fermentation process } \\
\text { was by gradual additional of } \\
\text { substrate instead of starting with high } \\
\text { substrate concentration }\end{array}$ \\
\hline
\end{tabular}

This novel approach of using household waste as a substrate to produce SA provides the information on how to accomplish a fermentation process using either A. succinogenes or B. succiniciproducens. The research will be a benchmark for fellow researchers to utilize other home-grown or local products in the production of SA. Additionally, this study proves the ability of B. succiniciproducens to be an alternative as a bacterium capable of converting $\mathrm{CO}_{2}$ content in biogas into SA. Nevertheless, further studies still need to be done on other bacteria to identify the possibilities of upgrading biogas while producing SA.

\subsection{Future Perspective of Succinic Acid Production}

These studies proved that both biomethane and biochemical (SA) can be produced by utilizing unconventional biomasses. To further improve the utilization of $\mathrm{CO}_{2}$ in biogas, research can be done on metabolic engineering of some other bacteria to produce higher SA titer with no by-products. On top of using A. succinogenes 130Z (DSM 22257) and B. succiniciproducens (DSM 22022), other bacterial strains had been identified that hold a potential to convert $\mathrm{CO}_{2}$ in biogas into SA. Fermentation techniques are also a factor in increasing the SA titer. Some of the bacterial strain and fermentation techniques that can possibly be integrated into SA fermentation technique are listed in Table 6. Although these studies were aimed at the direct conversion of $\mathrm{CO}_{2}$ into SA, it will set a base for further research on integrating it in simultaneous biogas upgrading.

Additionally, to implement this technology on a larger scale, further improvement of the simultaneous biogas upgrading, and succinic acid production technology is required. Because there is still no available matured technology in the market, cost breakdown cannot be conducted. Nevertheless, the demand for bio-SA has been increasing over the years. By selling the produced SA, it will reduce the cost of whole operation. Market forecast of bio-SA was conducted by different researchers and can be seen in a simplified form in Figure 9. This reflects the relevance of producing bio-SA in the future. 
Table 6. Summary of performances of succinic acid fermentation studies by various microorganisms.

\begin{tabular}{|c|c|c|c|c|c|}
\hline Microorganism & $\begin{array}{l}\text { Reactor Type/ } \\
\text { Fermentation } \\
\text { Technique }\end{array}$ & Substrate & Titer $(\mathrm{g} / \mathrm{L})$ & Yield (g/g) & Reference \\
\hline A. succinogenes & Repeat-batch & Glucose & 33.9 & 0.86 & [99] \\
\hline A. succinogenes $130 \mathrm{Z}$ & Suspended cell & Glucose & 10.4 & $0.27-0.73$ & [99] \\
\hline A. succinogenes $130 \mathrm{Z}$ & Recycled cell & Glucose & 18.6 & $0.50-0.59$ & [100] \\
\hline A. succinogenes $130 \mathrm{Z}$ & Batch & Whey & 21.5 & 0.57 & [101] \\
\hline A. succinogenes $130 \mathrm{Z}$ & Continuous & Corn & 39.6 & 0.78 & [102] \\
\hline A. succinogenes FZ53 & Batch & Glucose & 105.8 & 0.8 & [103] \\
\hline M. succiniciproducens & Batch & Glucose & 14 & 0.7 & [104] \\
\hline M. succiniciproducens & Batch & Whey & 13.5 & 0.72 & [105] \\
\hline $\begin{array}{l}\text { M. succiniciproducens } \\
\text { MBEL55E }\end{array}$ & Suspended cell & Lactose & 10.3 & $0.63-0.69$ & [105] \\
\hline $\begin{array}{l}\text { M. succiniciproducens } \\
\text { MBEL55E }\end{array}$ & Suspended cell & $\begin{array}{l}\text { Glucose } \\
\text { Xylose }\end{array}$ & 14.1 & $0.34-0.61$ & [100] \\
\hline $\begin{array}{l}\text { M. succiniciproducens } \\
\text { MBEL55E }\end{array}$ & Recycled cell & Glucose & 12.8 & $0.48-0.64$ & [100] \\
\hline M. succiniciproducens LPK7 & Recycled cell & Glucose & 12.9 & $0.10-0.71$ & [106] \\
\hline A. succiniciproducens & Continuous & Whey & 24 & 0.72 & [103] \\
\hline $\begin{array}{l}\text { A. succiniciproducens ATCC } \\
\text { No. } 29305\end{array}$ & Suspended cell & Lactose & 24.0 & $0.62-0.72$ & [107] \\
\hline $\begin{array}{l}\text { A. succiniciproducens ATCC } \\
\text { No. } 29305\end{array}$ & Suspended cell & Lactose & 14.0 & $0.81-0.94$ & [108] \\
\hline $\begin{array}{l}\text { A. succiniciproducens ATCC } \\
\text { No. } 29305\end{array}$ & Suspended cell & Glucose & 29.6 & $0.73-0.82$ & [109] \\
\hline $\begin{array}{l}\text { A. succiniciproducens ATCC } \\
\text { No. } 29305\end{array}$ & Suspended cell & Glycerol & 16.1 & $1.23-1.50$ & [110] \\
\hline $\begin{array}{c}\text { A. succiniciproducens ATCC } \\
\text { No. } 53488\end{array}$ & Recycled cell & Glucose & 16.5 & $0.74-0.83$ & [111] \\
\hline
\end{tabular}

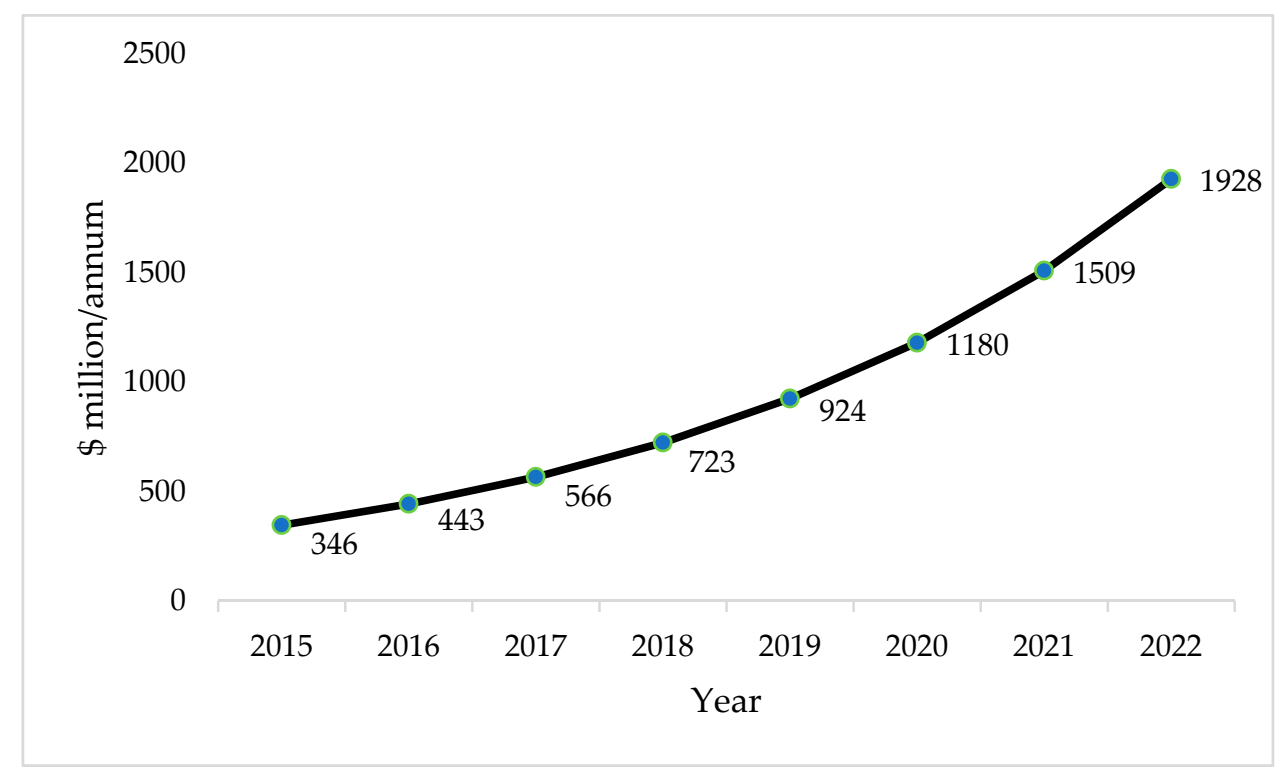

Figure 9. Market forecast of bio-SA volume from the year 2015 to 2022 [112].

The evaluation of the performance of microbial conversion of $\mathrm{CO}_{2}$ into $\mathrm{SA}$ is an important step in providing practical solutions, knowledge, and addressing the gaps in the current understanding [113]. While SA is still widely produced from petrochemical and glucose because of ubiquitous substrate availability, simple process design and high productivities, effort toward producing SA from $\mathrm{CO}_{2}$ 
as sustainable source is still growing and will be applicable if technical barriers that needed to be identified such as limiting gas transfer rates can be overcome [114].

\section{Conclusions}

Global industrial emission of carbon dioxide had risen to an all-time high in 2018 and it is unlikely to reduce soon $[115,116]$. Growing demand for oil and natural gas globally overshadowed the effort in the development of renewable energy. Furthermore, fossil-fuel infrastructure is still expanding, particularly in developing countries. If current trends continue, the fear of the worst effects of global warming - extreme weather, rising sea levels, plant and animal extinctions, ocean acidification, major shifts in climate, and unprecedented social upheaval-will be inevitable. One of the solutions for these problems is the utilization of bio-natural gas as the substitutes for fossil fuels. In fact, biogas reduces the emission of carbon dioxide while capturing methane, ensuring a cleaner environment. While these are major leaps toward cleaner fuels, still there is room for improvement. Major research had been made from time to time on the techniques to upgrade the biogas to a higher degree. Throughout the years, various technologies and techniques had been developed on how to fully utilize biogas and its by-product so there is no waste release into the environment. One major hurdle for biogas implementation is the cost which hurts its potential employment. While biogas is not the perfect solution for global greenhouse gas emissions, its place in the world of waste management has been very much solidified and will continue to evolve in the coming years.

Author Contributions: Conceptualization-S.N. and A.I.A.; writing, original draft preparation-S.N. and A.I.A.; writing, review, and editing-S.N., K.W.C., and M.Y.O.; writing, proofreading-A.I.A., K.W.C., and P.L.S.; funding acquisition-S.N.

Funding: The authors (SN and AIA) would like to thank the Ministry of Education (MOE) Malaysia for the financial support through the Fundamental Research Grant Scheme (MOHE Project Ref. No.: FRGS/1/2018/STG01/UNITEN/01/1). A note of appreciation to iRMC UNITEN for supporting the publication of this paper through publication fund BOLD 2025 (RJO10436494). AIA also wishes to express his gratitude to UNITEN for providing the UNITEN Postgraduate Scholarship 2019.

Acknowledgments: The authors would like to express their special thanks to Universiti Tenaga Nasional for providing facilities and equipment to ensure the accomplishment of this project.

Conflicts of Interest: The authors declare that they have no competing interests.

\section{References}

1. Höök, M.; Tang, X. Depletion of fossil fuels and anthropogenic climate change-A review. Energy Policy 2013, 52, 797-809. [CrossRef]

2. Goede, A.; van de Sanden, R. $\mathrm{CO}_{2}$-Neutral fuels. Europhys. News 2016, 47, 22-26. [CrossRef]

3. Ragauskas, A.J.; Williams, C.K.; Davison, B.H.; Britovsek, G.; Cairney, J.; Eckert, C.A.; Frederick, W.J.J.; Hallett, J.P.; Leak, D.J.; Liotta, C.L.; et al. The path forward for biofuels and biomaterials. Science 2006, 311, 484-489. [CrossRef] [PubMed]

4. Masse, D.I.; Talbot, G.; Gilbert, Y. A scientific review of the agronomic, environmental and social benefits of anaerobic digestion. In Anaerobic Digestions; Caruana, D.J., Olsen, E.A., Eds.; Nova Science Publishers: New York, NY, USA, 2012; pp. 109-131. ISBN 978-1-62081-610-3.

5. Mata-Alvarez, J.; Macé, S.; Llabrés, P. Anaerobic digestion of organic solid wastes: An overview of research achievements and perspectives. Bioresour. Technol. 2000, 74, 3-16. [CrossRef]

6. Muhammad Nasir, I.; Mohd Ghazi, T.I.; Omar, R. Production of biogas from solid organic wastes through anaerobic digestion: A review. Appl. Microbiol. Biotechnol. 2012, 95, 321-329. [CrossRef]

7. Carlsson, M.; Lagerkvist, A.; Morgan-Sagastume, F. The effects of substrate pre-treatment on anaerobic digestion systems: A review. Waste Manag. 2012, 32, 1634-1650. [CrossRef]

8. Long, J.H.; Aziz, T.N.; Reyes, F.L.; de los Ducoste, J.J. Anaerobic co-digestion of fat, oil, and grease (FOG): A review of gas production and process limitations. Process Saf. Environ. Prot. 2012, 90, 231-245. [CrossRef]

9. Montalvo, S.; Guerrero, L.; Borja, R.; Sánchez, E.; Milán, Z.; Cortés, I.; de la la Rubia, M.A. Application of natural zeolites in anaerobic digestion processes: A review. Appl. Clay Sci. 2012, 58, 125-133. [CrossRef] 
10. Raboni, M.; Urbini, G. Production and use of biogas in Europe: A survey of current status and perspectives. Ambient. Agua 2014, 9. [CrossRef]

11. Kárászová, M.; Sedláková, Z.; Izák, P. Gas permeation processes in biogas upgrading: A short review. Chem. Pap. 2015, 69, 1277-1283. [CrossRef]

12. Sun, Q.; Li, H.; Yan, J.; Liu, L.; Yu, Z.; Yu, X. Selection of appropriate biogas upgrading technology-A review of biogas cleaning, upgrading and utilisation. Renew. Sustain. Energy Rev. 2015, 51, 521-532. [CrossRef]

13. Kougias, P.G.; Treu, L.; Benavente, D.P.; Boe, K.; Campanaro, S.; Angelidaki, I. Ex-situ biogas upgrading and enhancement in different reactor systems. Bioresour. Technol. 2017, 225, 429-437. [CrossRef] [PubMed]

14. Abatzoglou, N.; Boivin, S. A review of biogas purification processes. Biofuels Bioprod. Biorefin. 2009, 3, 42-71. [CrossRef]

15. Ryckebosch, E.; Drouillon, M.; Vervaeren, H. Techniques for transformation of biogas to biomethane. Biomass Bioenergy 2011, 35, 1633-1645. [CrossRef]

16. Bauer, F.; Persson, T.; Hulteberg, C.; Tamm, D. Biogas upgrading-Technology overview, comparison and perspectives for the future. Biofuels Bioprod Biorefin. 2013, 7, 499-511. [CrossRef]

17. Aziz, N.I.H.A.; Hanafiah, M.M.; Gheewala, S.H. A review on life cycle assessment of biogas production: Challenges and future perspectives in Malaysia. Biomass Bioenergy 2019, 122, 361-374. [CrossRef]

18. García-Gutiérrez, P.; Jacquemin, J.; McCrellis, C.; Dimitriou, I.; Taylor, S.F.R.; Hardacre, C.; Allen, R.W.K. Techno-economic feasibility of selective $\mathrm{CO}_{2}$ capture processes from biogas streams using ionic liquids as physical absorbents. Energy Fuels 2016, 30, 5052-5064. [CrossRef]

19. Andriani, D.; Wresta, A.; Atmaja, T.D.; Saepudin, A. A review on optimization production and upgrading biogas through $\mathrm{CO}_{2}$ removal using various techniques. Appl. Biochem. Biotechnol. 2014, 172, 1909-1928. [CrossRef]

20. Awe, O.W.; Zhao, Y.; Nzihou, A.; Minh, D.P.; Lyczko, N. A Review of biogas utilisation, purification and upgrading technologies. Waste Biomass Valoriz. 2017, 8, 267-283. [CrossRef]

21. Leonzio, G. Upgrading of biogas to bio-methane with chemical absorption process: Simulation and environmental impact. J. Clean. Prod. 2016, 131, 364-375. [CrossRef]

22. Xia, A.; Cheng, J.; Murphy, J.D. Innovation in biological production and upgrading of methane and hydrogen for use as gaseous transport biofuel. Biotechnol. Adv. 2016, 34, 451-472. [CrossRef] [PubMed]

23. Patterson, T.; Esteves, S.; Dinsdale, R.; Guwy, A. An evaluation of the policy and techno-economic factors affecting the potential for biogas upgrading for transport fuel use in the UK. Energy Policy 2011, 39, 1806-1816. [CrossRef]

24. Angelidaki, I.; Treu, L.; Tsapekos, P.; Luo, G.; Campanaro, S.; Wenzel, H.; Kougias, P.G. Biogas upgrading and utilization: Current status and perspectives. Biotechnol. Adv. 2018, 36, 452-466. [CrossRef] [PubMed]

25. Tock, L.; Gassner, M.; Maréchal, F. Thermochemical production of liquid fuels from biomass: Thermo-economic modeling, process design and process integration analysis. Biomass Bioenergy 2010, 34, 1838-1854. [CrossRef]

26. Zhao, Q.; Leonhardt, E.; MacConnell, C.; Frear, C.; Chen, S. Purification technologies for biogas generated by anaerobic digestion. In Climate Friendly Farming_Final Report; Center for Sustaining Agriculture and Natural Resources: Washington, DC, USA, 2010; p. 24.

27. Hoyer, K.; Hulteberg, C.; Svensson, M.; Jenberg, J.; NØrregÅrd, Ø. Biogas Upgrading: A Technical Review; Energiforsk: Stockholm, Sweeden, 2016; ISBN 9789176732755.

28. Zhou, K.; Chaemchuen, S.; Verpoort, F. Alternative materials in technologies for biogas upgrading via $\mathrm{CO}_{2}$ capture. Renew. Sustain. Energy Rev. 2017, 79, 1414-1441. [CrossRef]

29. Ullah Khan, I.; Hafiz Dzarfan Othman, M.; Hashim, H.; Matsuura, T.; Ismail, A.F.; Rezaei-DashtArzhandi, M.; Wan Azelee, I. Biogas as a renewable energy fuel-A review of biogas upgrading, utilisation and storage. Energy Convers. Manag. 2017, 150, 277-294. [CrossRef]

30. Lasocki, J.; Kołodziejczyk, K.; Matuszewska, A. Laboratory-scale investigation of biogas treatment by removal of hydrogen sulfide and carbon dioxide. Polish J. Environ. Stud. 2015, 24, 1427-1434. [CrossRef]

31. Georgiou, D.; Petrolekas, P.D.; Hatzixanthis, S.; Aivasidis, A. Absorption of carbon dioxide by raw and treated dye-bath effluents. J. Hazard. Mater. 2007, 144, 369-376. [CrossRef]

32. Deng, L.; Hägg, M.B. Techno-economic evaluation of biogas upgrading process using $\mathrm{CO}_{2}$ facilitated transport membrane. Int. J. Greenh. Gas Control 2010, 4, 638-646. [CrossRef] 
33. Ho, M.T.; Allinson, G.W.; Wiley, D.E. Reducing the cost of $\mathrm{CO}_{2}$ capture from flue gases using pressure swing adsorption. Ind. Eng. Chem. Res. 2008, 47, 4883-4890. [CrossRef]

34. Augelletti, R.; Conti, M.; Annesini, M.C. Pressure swing adsorption for biogas upgrading. A new process configuration for the separation of biomethane and carbon dioxide. J. Clean. Prod. 2017, 140, 1390-1398. [CrossRef]

35. An, H.; Feng, B.; Su, S. $\mathrm{CO}_{2}$ capture by electrothermal swing adsorption with activated carbon fibre materials. Int. J. Greenh. Gas Control 2011, 5, 16-25. [CrossRef]

36. Plaza, M.G.; García, S.; Rubiera, F.; Pis, J.J.; Pevida, C. Post-combustion $\mathrm{CO}_{2}$ capture with a commercial activated carbon: Comparison of different regeneration strategies. Chem. Eng. J. 2010, 163, 41-47. [CrossRef]

37. Petersson, A.; Wellinger, A. Biogas Upgrading Technologies-Developments and Innovations; IEA Bioenergy: Paris, France, 2009; p. 20.

38. Bauer, F.; Hulteberg, C.; Persson, T.; Tamm, D.; Granskning, B. Biogas Upgrading—Review of Commercial Technologies; Svenskt Gastekniskt Center AB: Malmo, Sweeden, 2013.

39. Harasimowicz, M.; Orluk, P.; Zakrzewska-Trznadel, G.; Chmielewski, A.G. Application of polyimide membranes for biogas purification and enrichment. J. Hazard. Mater. 2007, 144, 698-702. [CrossRef]

40. Munoz, R.; Meier, L.; Diaz, I.; Jeison, D. A review on the state-of-the-art of physical/chemical and biological technologies for biogas upgrading. Rev. Environ. Sci. Biotechnol. 2015, 14, 727-759. [CrossRef]

41. Green, D.W.; Perry, R.H. Perry's Chemical Engineers' Hand Book, 8th ed.; McGraw-Hill: New York, NY, USA, 2008.

42. Grande, C.A.; Blom, R. Cryogenic adsorption of methane and carbon dioxide on zeolites 4A and 13X. Energy Fuels 2014, 28, 6688-6693. [CrossRef]

43. Marsh, M.; Officer, C.E.; Krich, K.; Krich, K.; Augenstein, D.; Benemann, J.; Rutledge, B.; Salour, D. Biomethane from Dairy Waste: A Sourcebook for the Production and Use of Renewable Natural Gas in California; Suscon: San Francisco, CA, USA, 2005.

44. Cecchi, F.; Cavinato, C. Anaerobic digestion of bio-waste: A mini-review focusing on territorial and environmental aspects. Waste Manag. Res. 2015, 33, 429-438. [CrossRef]

45. Gao, Y.; Jiang, J.; Meng, Y.; Yan, F.; Aihemaiti, A. A review of recent developments in hydrogen production via biogas dry reforming. Energy Convers. Manag. 2018, 171, 133-155. [CrossRef]

46. Aresta, M. Carbon Dioxide as Chemical Feedstock, 1st ed.; Wiley-VCH: Weinheim, Germany, 2010.

47. Williams, M. The merck index: An encyclopedia of chemicals, drugs, and biologicals, 14th ed.; Merck Inc.: Rahway, NJ, USA, 2006; 2564p.

48. Stangeland, K.; Kalai, D.; Li, H.; Yu, Z. $\mathrm{CO}_{2}$ Methanation: The effect of catalysts and reaction conditions. Energy Procedia 2017, 105, 2022-2027. [CrossRef]

49. Jürgensen, L.; Augustine, E.; Born, J.; Holm-nielsen, J.B. Bioresource technology dynamic biogas upgrading based on the Sabatier process: Thermodynamic and dynamic process simulation. Bioresource Technol. 2015, 178, 323-329.

50. U.S. Energy Information Administration (EIA). International Energy Outlook 2017; EIA: Washington, DC, USA, 2017.

51. Su, X.; Xu, J.; Liang, B.; Duan, H.; Hou, B.; Huang, Y. Catalytic carbon dioxide hydrogenation to methane: A review of recent studies. J. Energy Chem. 2016, 25, 553-565. [CrossRef]

52. Hashemnejad, S.M.; Parvari, M. Deactivation and regeneration of nickel-based catalysts for steam-methane reforming. Chin. J. Catal. 2011, 32, 273-279. [CrossRef]

53. Mutz, B.; Gänzler, A.M.; Nachtegaal, M.; Müller, O.; Frahm, R.; Kleist, W.; Grunwaldt, J.-D. Surface oxidation of supported ni particles and its impact on the catalytic performance during dynamically operated methanation of $\mathrm{CO}_{2}$. Catalysts 2017, 7, 279. [CrossRef]

54. National Academies of Sciences Engineering and Medicine Gaseous Carbon Waste Streams Utilization. In Gaseous Carbon Waste Streams Utilization: Status and Research Needs; The National Academies Press: Washington, DC, USA, 2019; pp. 63-95. ISBN 978-0-309-48336-0.

55. Manthiram, K.; Beberwyck, B.J.; Alivisatos, A.P. Enhanced electrochemical methanation of carbon dioxide with a dispersible nanoscale copper catalyst. J. Am. Chem. Soc. 2014, 136, 13319-13325. [CrossRef]

56. Qiu, Y.-L.; Zhong, H.-X.; Zhang, T.-T.; Xu, W.-B.; Li, X.-F.; Zhang, H.-M. Copper electrode fabricated via pulse electrodeposition: Toward high methane selectivity and activity for $\mathrm{CO}_{2}$ electroreduction. ACS Catal. 2017, 7, 6302-6310. [CrossRef] 
57. Sun, X.; Kang, X.; Zhu, Q.; Ma, J.; Yang, G.; Liu, Z.; Han, B. Very highly efficient reduction of $\mathrm{CO}_{2}$ to $\mathrm{CH}_{4}$ using metal-free N-doped carbon electrodes. Chem. Sci. 2016, 7, 2883-2887. [CrossRef]

58. Álvarez, A.; Bansode, A.; Urakawa, A.; Bavykina, A.V.; Wezendonk, T.A.; Makkee, M.; Gascon, J.; Kapteijn, F. Challenges in the greener production of formates/formic acid, methanol, and DME by heterogeneously catalyzed $\mathrm{CO}_{2}$ hydrogenation processes. Chem. Rev. 2017, 117, 9804-9838. [CrossRef]

59. Ganesh, I. Conversion of carbon dioxide into methanol-A potential liquid fuel: Fundamental challenges and opportunities (a review). Renew. Sustain. Energy Rev. 2014, 31, 221-257. [CrossRef]

60. Pérez-Fortes, M.; Schöneberger, J.C.; Boulamanti, A.; Tzimas, E. Methanol synthesis using captured $\mathrm{CO}_{2}$ as raw material: Techno-economic and environmental assessment. Appl. Energy 2016, 161, 718-732. [CrossRef]

61. Saeidi, S.; Aishah, N.; Amin, S.; Reza, M. Hydrogenation of $\mathrm{CO}_{2}$ to value-added products-A review and potential future developments. Biochem. Pharmacol. 2014, 5, 66-81. [CrossRef]

62. Klankermayer, J.; Wesselbaum, S.; Beydoun, K.; Leitner, W. Selective catalytic synthesis using the combination of carbon dioxide and hydrogen: Catalytic chess at the interface of energy and chemistry. Angew. Chemie Int. Ed. 2016, 55, 7296-7343. [CrossRef] [PubMed]

63. Wang, W.-H.; Himeda, Y.; Muckerman, J.T.; Manbeck, G.F.; Fujita, E. $\mathrm{CO}_{2}$ Hydrogenation to formate and methanol as an alternative to photo- and electrochemical $\mathrm{CO}_{2}$ reduction. Chem. Rev. 2015, 115, 12936-12973. [CrossRef] [PubMed]

64. Liu, Y.; Zhang, Y.; Wang, T.; Tsubaki, N. Efficient conversion of carbon dioxide to methanol using copper catalyst by a new low-temperature hydrogenation process. Chem. Lett. 2007, 36, 1182-1183. [CrossRef]

65. Alper, E.; Yuksel Orhan, O. $\mathrm{CO}_{2}$ Utilization: Developments in conversion processes. Petroleum 2017, 3, 109-126. [CrossRef]

66. Rahimpour, M.R. A two-stage catalyst bed concept for conversion of carbon dioxide into methanol. Fuel Process. Technol. 2008, 89, 556-566. [CrossRef]

67. Sun, X.; Zhu, Q.; Kang, X.; Liu, H.; Qian, Q.; Zhang, Z.; Han, B. Molybdenum-Bismuth bimetallic chalcogenide nanosheets for highly efficient electrocatalytic reduction of carbon dioxide to methanol. Angew. Chemie Int. Ed. 2016, 55, 6771-6775. [CrossRef] [PubMed]

68. Wang, W.; Wang, S.; Ma, X.; Gong, J. Recent advances in catalytic hydrogenation of carbon dioxide. Chem. Soc. Rev. 2011, 40, 3703-3727. [CrossRef]

69. Qiao, J.; Liu, Y.; Hong, F.; Zhang, J. A review of catalysts for the electroreduction of carbon dioxide to produce low-carbon fuels. Chem. Soc. Rev. 2014, 43, 631-675. [CrossRef]

70. White, J.L.; Baruch, M.F.; Pander, J.E.; Hu, Y.; Fortmeyer, I.C.; Park, J.E.; Zhang, T.; Liao, K.; Gu, J.; Yan, Y.; et al. Light-Driven heterogeneous reduction of carbon dioxide: Photocatalysts and photoelectrodes. Chem. Rev. 2015, 115, 12888-12935. [CrossRef]

71. Wu, M.; Zhang, W.; Ji, Y.; Yi, X.; Ma, J.; Wu, H.; Jiang, M. Coupled $\mathrm{CO}_{2}$ fixation from ethylene oxide off-gas with bio-based succinic acid production by engineered recombinant Escherichia coli. Biochem. Eng. J. 2017, 117, 1-6. [CrossRef]

72. Jürgensen, L.; Ehimen, E.A.; Born, J.; Holm-Nielsen, J.B. Utilization of surplus electricity from wind power for dynamic biogas upgrading: Northern Germany case study. Biomass Bioenergy 2014, 66, 126-132. [CrossRef]

73. Singhal, S.; Agarwal, S.; Arora, S.; Sharma, P.; Singhal, N. Upgrading techniques for transformation of biogas to bio-CNG: A review. Int. J. Energy Res. 2017, 41, 1657-1669. [CrossRef]

74. Stams, A.J.M.; Plugge, C.M. Electron transfer in syntrophic communities of anaerobic bacteria and archaea. Nat. Rev. Microbiol. 2009, 7, 568. [CrossRef] [PubMed]

75. Schuchmann, K.; Müller, V. Autotrophy at the thermodynamic limit of life: A model for energy conservation in acetogenic bacteria. Nat. Rev. Microbiol. 2014, 12, 809. [CrossRef] [PubMed]

76. Demirel, B.; Scherer, P. The roles of acetotrophic and hydrogenotrophic methanogens during anaerobic conversion of biomass to methane: A review. Rev. Environ. Sci. Biotechnol. 2008, 7, 173-190. [CrossRef]

77. Luo, G.; Angelidaki, I. Integrated biogas upgrading and hydrogen utilization in an anaerobic reactor containing enriched hydrogenotrophic methanogenic culture. Biotechnol. Bioeng. 2012, 109, 2729-2736. [CrossRef]

78. Bassani, I.; Kougias, P.G.; Treu, L.; Angelidaki, I. Biogas upgrading via hydrogenotrophic methanogenesis in two-stage continuous stirred tank reactors at mesophilic and thermophilic conditions. Environ. Sci. Technol. 2015, 49, 12585-12593. [CrossRef] [PubMed] 
79. Luo, G.; Angelidaki, I. Co-digestion of manure and whey for in situ biogas upgrading by the addition of $\mathrm{H} 2$ : Process performance and microbial insights. Appl. Microbiol. Biotechnol. 2013, 97, 1373-1381. [CrossRef]

80. Batstone, D.J.; Keller, J.; Angelidaki, I.; Kalyuzhnyi, S.V.; Pavlostathis, S.G.; Rozzi, A.; Sanders, W.T.; Siegrist, H.; Vavilin, V.A. The IWA anaerobic digestion model No 1 (ADM1). Water Sci. Technol. 2002, 45, 65-73. [CrossRef]

81. Mulat, D.G.; Mosbæk, F.; Ward, A.J.; Polag, D.; Greule, M.; Keppler, F.; Nielsen, J.L.; Feilberg, A. Exogenous addition of $\mathrm{H} 2$ for an in situ biogas upgrading through biological reduction of carbon dioxide into methane. Waste Manag. 2017, 68, 146-156. [CrossRef]

82. Luo, G.; Johansson, S.; Boe, K.; Xie, L.; Zhou, Q.; Angelidaki, I. Simultaneous hydrogen utilization and in situ biogas upgrading in an anaerobic reactor. Biotechnol. Bioeng. 2012, 109, 1088-1094. [CrossRef] [PubMed]

83. Fasihi, M.; Bogdanov, D.; Breyer, C. Techno-Economic assessment of power-to-liquids (PtL) fuels production and global trading based on hybrid pv-wind power plants. Energy Procedia 2016, 99, 243-268. [CrossRef]

84. Caldera, U. Role of seawater desalination in the management of an integrated water and $100 \%$ renewable energy based power sector in Saudi Arabia. Water 2018, 10, 3. [CrossRef]

85. Fasihi, M.; Bogdanov, D.; Breyer, C. Long-Term hydrocarbon trade options for the Maghreb Region and Europe-Renewable energy based synthetic fuels for a net zero emissions world. Sustainability 2017, 9, 306. [CrossRef]

86. Lövenich, A.; Fasihi, M.; Graf, A.; Kasten, P.; Langenheld, A.; Meyer, K.; Peter, F.; Podewils, C. The Future Cost of Electricity-Based Synthetic Fuels; Frontier Economics Ltd.: Cologne, Germany, 2018.

87. Zhang, C.; Jun, K.-W.; Gao, R.; Kwak, G.; Park, H.-G. Carbon dioxide utilization in a gas-to-methanol process combined with $\mathrm{CO}_{2} /$ Steam-mixed reforming: Techno-economic analysis. Fuel 2017, 190, 303-311. [CrossRef]

88. Stokes, H.C. The Economics of Methanol Production; The Stokes Consulting Group: Naples, FL, USA, 2002.

89. Mazière, A.; Prinsen, P.; García, A.; Luque, R.; Len, C. A review of progress in (bio)catalytic routes from/to renewable succinic acid. Biofuels Bioprod. Biorefin. 2017, 11, 908-931. [CrossRef]

90. Valderrama-Gomez, M.A.; Kreitmayer, D.; Wolf, S.; Marin-Sanguino, A.; Kremling, A. Application of theoretical methods to increase succinate production in engineered strains. Bioprocess Biosyst. Eng. 2017, 40, 479-497. [CrossRef]

91. Adom, F.; Dunn, J.B.; Han, J.; Sather, N. Life-Cycle fossil energy consumption and greenhouse gas emissions of bioderived chemicals and their conventional counterparts. Environ. Sci. Technol. 2014, 48, 14624-14631. [CrossRef]

92. Cheng, K.-K.; Zhao, X.-B.; Zeng, J.; Zhang, J.-A. Biotechnological production of succinic acid: Current state and perspectives. Biofuels Bioprod. Biorefin. 2012, 6, 302-318. [CrossRef]

93. Mohan, S.V.; Modestra, J.A.; Amulya, K.; Butti, S.K.; Velvizhi, G. A circular bioeconomy with biobased products from $\mathrm{CO}_{2}$ sequestration. Trends Biotechnol. 2016, 34, 506-519. [CrossRef]

94. Cao, W.; Wang, Y.; Luo, J.; Yin, J.; Xing, J.; Wan, Y. Effectively converting carbon dioxide into succinic acid under mild pressure with Actinobacillus succinogenes by an integrated fermentation and membrane separation process. Bioresour. Technol. 2018, 266, 26-33. [CrossRef] [PubMed]

95. Cukalovic, A.; Stevens, C. V Feasibility of production methods for succinic acid derivatives: A marriage of renewable resources and chemical technology. Biofuels Bioprod. Biorefin. 2008, 2, 505-529. [CrossRef]

96. Gunnarsson, I.B.; Alvarado-Morales, M.; Angelidaki, I. Utilization of $\mathrm{CO}_{2}$ fixating bacterium Actinobacillus succinogenes $130 \mathrm{Z}$ for simultaneous biogas upgrading and biosuccinic acid production. Environ. Sci. Technol. 2014, 48, 12464-12468. [CrossRef] [PubMed]

97. Ballmann, P.; Dröge, S.; Wilkens, M. Integrated succinic acid production using lignocellulose and carbon dioxide from biogas plants. Chemie Ing. Tech. 2018, 90, 1253. [CrossRef]

98. Babaei, M.; Tsapekos, P.; Alvarado-Morales, M.; Hosseini, M.; Ebrahimi, S.; Niaei, A.; Angelidaki, I. Valorization of organic waste with simultaneous biogas upgrading for the production of succinic acid. Biochem. Eng. J. 2019, 147, 136-145. [CrossRef]

99. Urbance, S.E.; Pometto, A.L., III; Dispirito, A.A.; Denli, Y. Evaluation of succinic acid continuous and repeat-batch biofilm fermentation by Actinobacillus succinogenes using plastic composite support bioreactors. Appl. Microbiol. Biotechnol. 2004, 65, 664-670. [CrossRef]

100. Kim, D.Y.; Yim, S.C.; Lee, P.C.; Lee, W.G.; Lee, S.Y.; Chang, H.N. Batch and continuous fermentation of succinic acid from wood hydrolysate by Mannheimia succiniciproducens MBEL55E. Enzyme Microb. Technol. 2004, 35, 648-653. [CrossRef] 
101. Wan, C.; Li, Y.; Shahbazi, A.; Xiu, S. Succinic acid production from cheese whey using Actinobacillus succinogenes 130 Z. Appl. Biochem. Biotechnol. 2008, 145, 111-119. [CrossRef]

102. Bradfield, M.F.A.; Mohagheghi, A.; Salvachúa, D.; Smith, H.; Black, B.A.; Dowe, N.; Beckham, G.T.; Nicol, W. Continuous succinic acid production by Actinobacillus succinogenes on xylose-enriched hydrolysate. Biotechnol. Biofuels 2015, 8, 181. [CrossRef]

103. Song, H.; Lee, S.Y. Production of succinic acid by bacterial fermentation. Enzyme Microb. Technol. 2006, 39, 352-361. [CrossRef]

104. Lee, P.C.; Lee, S.Y.; Hong, S.H.; Chang, H.N. Isolation and characterization of a new succinic acid-producing bacterium, Mannheimia succiniciproducens MBEL55E, from bovine rumen. Appl. Microbiol. Biotechnol. 2002, 58, 663-668. [PubMed]

105. Lee, P.C.; Lee, S.Y.; Hong, S.H.; Chang, H.N. Batch and continuous cultures of Mannheimia succiniciproducens MBEL55E for the production of succinic acid from whey and corn steep liquor. Bioprocess Biosyst. Eng. 2003, 26, 63-67. [CrossRef] [PubMed]

106. Jae Oh, I.; Lee, H.; Park, C.; Lee, S.Y.; Lee, J. Succinic acid production by continuous fermentation process using Mannheimia succiniciproducens LPK7. J. Microbiol. Biotechnol. 2008, 18, 908-912.

107. Samuelov, N.S.; Datta, R.; Jain, M.K.; Zeikus, J.G. Whey fermentation by Anaerobiospirillum succiniciproducens for production of a succinate-based animal feed additive. Appl. Environ. Microbiol. 1999, 65, 2260-2263. [PubMed]

108. Lee, P.C.; Lee, W.G.; Kwon, S.; Lee, S.Y.; Chang, H.N. Batch and continuous cultivation of Anaerobiospirillum succiniciproducens for the production of succinic acid from whey. Appl. Microbiol. Biotechnol. 2000, 54, $23-27$. [CrossRef] [PubMed]

109. Lee, P.C.; Lee, S.Y.; Chang, H.N. Kinetic study of organic acid formations and growth of Anaerobiospirillum succiniciproducens during continuous cultures. J. Microbiol. Biotechnol. 2009, 19, 1379-1384. [CrossRef]

110. Lee, P.C.; Lee, S.Y.; Chang, H.N. Kinetic study on succinic acid and acetic acid formation during continuous cultures of Anaerobiospirillum succiniciproducens grown on glycerol. Bioprocess Biosyst. Eng. 2010, 33, 465-471. [CrossRef] [PubMed]

111. Lee, P.-C.; Lee, S.-Y.; Chang, H.-N. Cell recycled culture of succinic acid-producing Anaerobiospirillum succiniciproducens using an internal membrane filtration system. J. Microbiol. Biotechnol. 2008, 18, 1252-1256.

112. Tan, J.P.; Jahim, J.; Harun, S.; Wu, T.Y. Overview of the Potential of Bio-Succinic Acid Production from Oil Palm Fronds. J. Phys. Sci. 2017, 28, 53-72.

113. Köhler, K.A.K.; Rühl, J.; Blank, L.M.; Schmid, A. Integration of biocatalyst and process engineering for sustainable and efficient n-butanol production. Eng. Life Sci. 2015, 15, 4-19. [CrossRef]

114. Liebal, U.W.; Blank, L.M.; Ebert, B.E. $\mathrm{CO}_{2}$ to succinic acid-Estimating the potential of biocatalytic routes. Metab. Eng. Commun. 2018, 7, 1-10. [CrossRef] [PubMed]

115. Figueres, C.; Le Quéré, C.; Mahindra, A.; Bäte, O.; Whiteman, G.; Peters, G.; Guan, D. Emissions are still rising: Ramp up the cuts. Nature 2018, 564, 27-30. [PubMed]

116. Le Quéré, C.; Andrew, R.M.; Friedlingstein, P.; Sitch, S.; Hauck, J.; Pongratz, J.; Pickers, P.; Korsbakken, J.I.; Peters, G.P.; Canadell, J.G. Global carbon budget 2018. Earth Syst. Sci. Data 2018, 10, 2141-2194. [CrossRef]

(C) 2019 by the authors. Licensee MDPI, Basel, Switzerland. This article is an open access article distributed under the terms and conditions of the Creative Commons Attribution (CC BY) license (http://creativecommons.org/licenses/by/4.0/). 